NBSIR 73-278 (4 Volumes)

Model Documents for the Evaluation, Approval, and Inspection of Manufactured Buildings

VOLUME III - EVALUATION AND APPROVAL DOCUMENTS

CES Project

Office of Building Standards and Codes Services

Center for Building Technology, IAT

National Bureau of Standards

Washington, D. C. 20234

September 1973

Preliminary Report

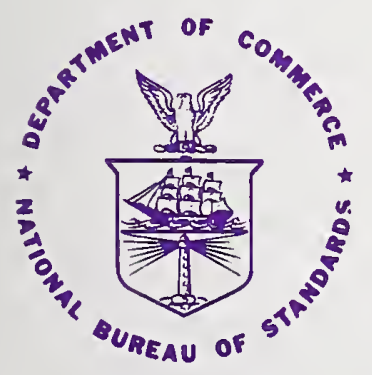

U.S. DEPARTMENT OF COMMERCE

NATIONAL BUREAU OF STANDARDS 



\section{MODEL DOCUMENTS FOR THE EVALUATION, APPROVAL, AND INSPECTION OF MANUFACTURED BUILDINGS}

VOLUME III - EVALUATION AND APPROVAL DOCUMENTS

R. D. Dikkers, H. R. Trechsel, P. W. Cooke, H. K. Tejuja, L. P. Zelenka

\section{CES Project}

Office of Building Standards and Codes Services

Center for Building Technology, IAT

National Bureau of Standards

Washington, D. C. 20234

September 1973

Preliminary Report

This is a preliminary report issued with the express intent to solicit comments and suggestions. Accordingly, results and conclusions contained herein are not necessarily those that will be included in the final report. 
In response to requests from the Executive Office of the President and the National Conference of States on Building Codes and Standards (NCSBCS), the National Bureau of standards has undertaken specific research programs to remove or reduce barriers created by the building regulatory process, so as to improve productivity and innovation in building construction. One of these programs is to establish a Cocrdinated Evaluation System (CES) by developing, in conjunction with the state governments, model informational documentation for use in the buildirg regulatory process.

This four-volume report outlines the results of an initial study of documentation needs, sample forms and checklists pertaining to manufactured buildings and components. It is a preliminary report issued with the expressed intent to solicit comments and sliggestions so that more comprehensive and more generaliy applicable model documentation can be developed.

A first draft of this report was reviewed during a 2 1/2 day meeting in April, 1973, by a group of conslitants composed of representatives of state and local buildirge officials, design professiorals, third party evaluation and inspection agencies, ard industrialized building marufacturers. The review meeting was organized and chaired by Mr. John Dunlap, Consulting Engineer of Sacramento, California. The other corsultants were:

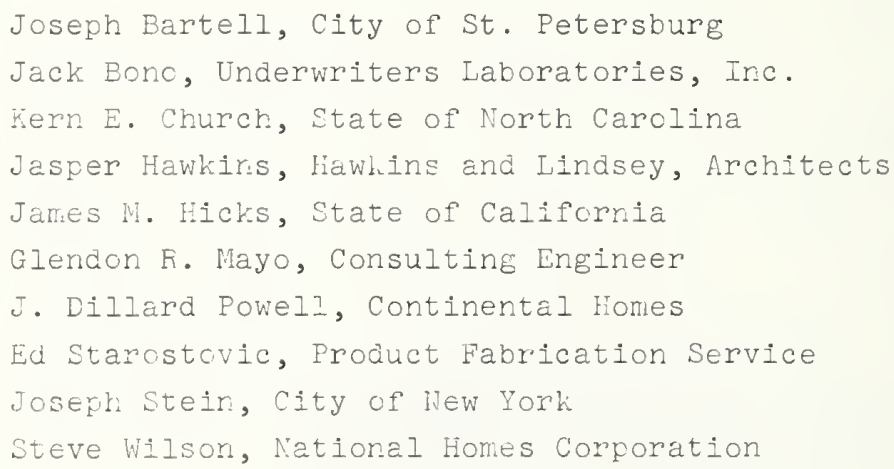

Ihe comments of the consultants were most helpful in developing the model docunerts cortaired ir this report, and their valuatle assistance is greatly appreciated and herevith acknowleaged. 
1. INTRODUCTION . . . . . . . . . . . . . . . . . . . . . . . . I

2. COORDINATED EVALUATION SYSTEM (CES) PROJECT . . . . . . . . . . . . . . 3

3. SCOPE OF CES MODEL INFORMATIONAL DOCUMENTATION . . . . . . . . . . . . . 4

4. REGULATORY PROCESS FOR MANUFACTURED BUILDINGS AND

4.1. Program Administration . . . . . . . . . . . . . . . . . 5

a. Initiation of Action . . . . . . . . . . . . . . . . . 7

4.2. Preparation and Submission . . . . . . . . . . . . . . . . 7

a. Building Systems . . . . . . . . . . . . . . . 8

b. Compliance Assurance Program . . . . . . . . . . . . . . . 8

c. Modifications and Variations... . . . . . . . . . . 8

4.3. Preliminary Review . . . . . . . . . . . . . . . . . 9

4.4. Evaluation ............................. 10

4.5. Approval and Disapproval . . . . . . . . . . . . . . . 10

a. Notice of Completed Evaluation............... . 10

b. Stamp of Approval . . . . . . . . . . . . . . . . 10

c. Building Systems Approval Report . . . . . . . . . . . . . . . 11

4.6. Fabrication, Inspection, Certification, Transportation
and Handing, and Installation....... . . . . . . . II

a. Fabrication . . . . . . . . . . . . . . . . . . . . . 11

b. Inspection and certification . . . . . . . . . . . . . 12

c. Transportation and Handling . . . . . . . . . . . . . . 12

d. Installation . . . . . . . . . . . . . . . . . . . . 12

4.7. Local Enforcement Activities. . . . . . . . . . . . . . . . . 13

4.8. Interstate Acceptance (Reciprocity) . . . . . . . . . . . . . . . 14

5. MODEL INFORMATIONAL DOCUMENTS . . . . . . . . . . . . . . . . . . 14

5.1. Use of Documents... . . . . . . . . . . . . . . . . . . 14

5.2. Submission . . . . . . . . . . . . . . . . . . . 14

a. Building Systems . . . . . . . . . . . . . . . . . . 15

b. Submission Requirements for Manufactured
Building Components . . . . . . . . . . . . 17

c. Compliance Assurance Program . . . . . . . . . . . . . . . 19

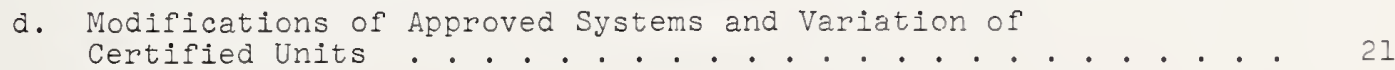


Page

5.3. Preliminary Review. . . . . . . . . . . . . . . . 23

5.4. Evaluation . . . . . . . . . . . . . . . . . 24 a. Building System . . . . . . . . . . . . . . . 25

b. Compliance Assurance Program . . . . . . . . . . . . . . . 28

5.5. Approval and Disapproval . . . . . . . . . . . . . . 30

5.6. Fabrication, Inspection, and Certification . . . . . . . . . . 31

5.7. Local Enforcement Agency Activities . . . . . . . . . . . . . . 33

a. Building Permit Application . . . . . . . . . . . . . . 33

b. Building Permit . . . . . . . . . . . . . . . . . 34

c. Local Enforcement Agency Violation Report . . . . . . . . . . 34

d. Certificates of Occupancy . . . . . . . . . . . . . . 34

5.8. Interstate Acceptance (Reciprocity) . . . . . . . . . . . . . 36

a. Introduction . . . . . . . . . . . . . . . 36

b. Prerequisite for Interstate Acceptance . . . . . . . . . 36

c. Process of Interstate faceptance. . . . . . . . . . . . . 37

d. Model Documents . . . . . . . . . . . . . . . 38

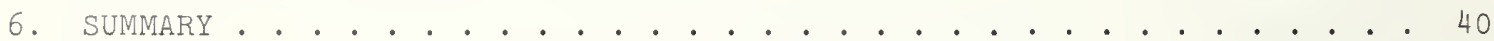

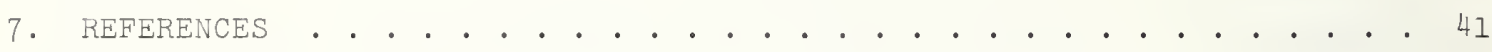

APPENDIXES . . . . . . . . . . . . . . . . . . . . . . . 43 
Document

Application for Building System and Compliance

Program Approval . . . . . . . . . . . . . . . . . 1

General Submission Requirements . . . . . . . . . . 5

S-03

Architectural Submission . . . . . . . . . . . . . . . 9

$S-04$

Structural Submission . . . . . . . . . . . . . . . 13

S-05

S-06

S-07

S-08

$S-09$

S-10

Mechanical Submission . . . . . . . . . . . . . . 19

Plumbing Submission . . . . . . . . . . . . . . . . 21

Electrical Submission . . . . . . . . . . . . . 23

Submission Requirements for Building Components . . . . . . . 27

Compliance Assurance Program . . . . . . . . . . . . . 29

Application for Approval of Minor Modification

to an Approved Building System and/or Compliance

Assurance Program . . . . . . . . . . . . . . . . 63

$S-11$

Application for Approval of Variation to a

Certified Manufactured Building or Component . . . . . . . . . 65

\section{VOLUME III - EVALUATION AND APPROVAL DOCUMENTS}

E-OI

Ë-02

E-03

E- 04

E-05

E-06

$\mathrm{E}-07$

$E-08$

E-09

$E-10$

E-11

$A-01$

A- 02

A-03
Processing Record . . . . . . . . . . . . . . . . . . . 1

Preliminary Review Checklist . . . . . . . . . . . . . 3

Submittal Unsuitable for Processing . . . . . . . . . . . . 7

Evaluation Checklist - Architectural . . . . . . . . . . . 9

Evaluation Checklist - Structural . . . . . . . . . . . 17

Evaluation Checklist - Mechanical . . . . . . . . . . 21

Evaluation Checklist - Plumbing . . . . . . . . . . . 25

Evaluation Checklist - Electrical . . . . . . . . . . 27

Certification of Products and Test Reports . . . . . . . . . . 31

Evaluation Checklist - Compliance Assurance Manual . . . . . 33

Manufacturing Facility Evaluation Report . . . . . . . . . 43

Notice of Completed Evaluation . . . . . . . . . . . 49

Stamps of Approval . . . . . . . . . . . . . . . . 51

Building System Approval Report . . . . . . . . . . . 55 
Document Number

$$
\begin{aligned}
& C-01 \\
& C-02 \\
& C-03 \\
& C-04 \\
& C-05 \\
& C-06 \\
& C-07 \\
& C-08
\end{aligned}
$$

$L-0 I$

$\mathrm{L}-02$

$\mathrm{I}-03$
VOLUME IV - CONPLIANCE ASSURANCE AND LOCAL ENFORCEMENT AGENCY DOCUMENTS

Page

Manufacturer's Data Plate . . . . . . . . . . . . . . . I

In-Plant Inspection Checklist . . . . . . . . . . . . . . . . 5

Inspection Report . . . . . . . . . . . . . . . . . . 75

Noncompliance Tag. . . . . . . . . . . . . . . . . 77

Prohibited Sales Notice . . . . . . . . . . . . . . . 79

Iotification of Susperded Activities . . . . . . . . . . . . 81

Label . . . . . . . . . . . . . . . . . . . . 83

Label Control Record . . . . . . . . . . . . . . . . 85

Standard Builaing Fermit Application Form . . . . . . . . . . 87

Manufactured Building Violation Report . . . . . . . . . . . . 89

Certificate of Occupancy . . . . . . . . . . . . . . . 9 9l 
MODEL DOCUMENTS FOR THE EVALUATION, APPROVAL, AND INSPECTION OF MANUFACTURED BUILDINGS

R. D. Dikkers, H. R. Trechsel, P. W. Cooke, H. K. Tejuja, L. P. Zelenka

To assist the states in developing their building regulatory activities and functions, the Coordinated Evaluation System (CES) Project has defined and developed model informational documentation pertaining to the functional areas of data submission, evaluation, approval, compliance assurance, installation data, and owner information.

This is a preliminary report which gives the results of the investigation to date, and presents discussions of informational needs and sample model documents pertaining to manufactured buildings and building components. The model documentation is based on the Model Rules and Regulations for manufactured buildings developed by a Department of Commerce sponsored working task group, and the results of a comprehensive state-of-the-art study of most of the existing state bullding regulatory programs. The documentation presented in this report covers all functional areas except owner information which is not usually subject to regulation and will be covered by a separate report. Emphasis was placed on developing documentation applicable primarily to one and two family detached dwellings.

Based on the comments received on this preliminary report, the documentation presented herein will be revised and a final report issued.

Key words: Building codes; certification; compliance assurance; evaluation; industrialized building; inspection; model documents; NCSBCS; standards; state regulation. 



\section{$\left[\begin{array}{c}\text { Name and Address of } \\ \text { Administrative Agency }\end{array}\right]$}

\section{PROCESSHG RECORD}

Name of Manufacturer

Address

Type of Application: $\square$ New System or Program $\square$ Major Modification
$\square$ Building System: Appl. No.
Date
$\square$ C.A.Program: Appl. No.
Date

DESCRIPTION :

A. Occupancy: $\square$ One and Two Family Detached $\square$ other (Specify)

B. Type of System: $\square$ Unitized Modular $\square$ core Unit $\square$ component
$\square$ Architectural
$\square$ Structural
$\square$ Mechanical
$\square$ Plumbing
Electrical
$\square$ other (Specify)

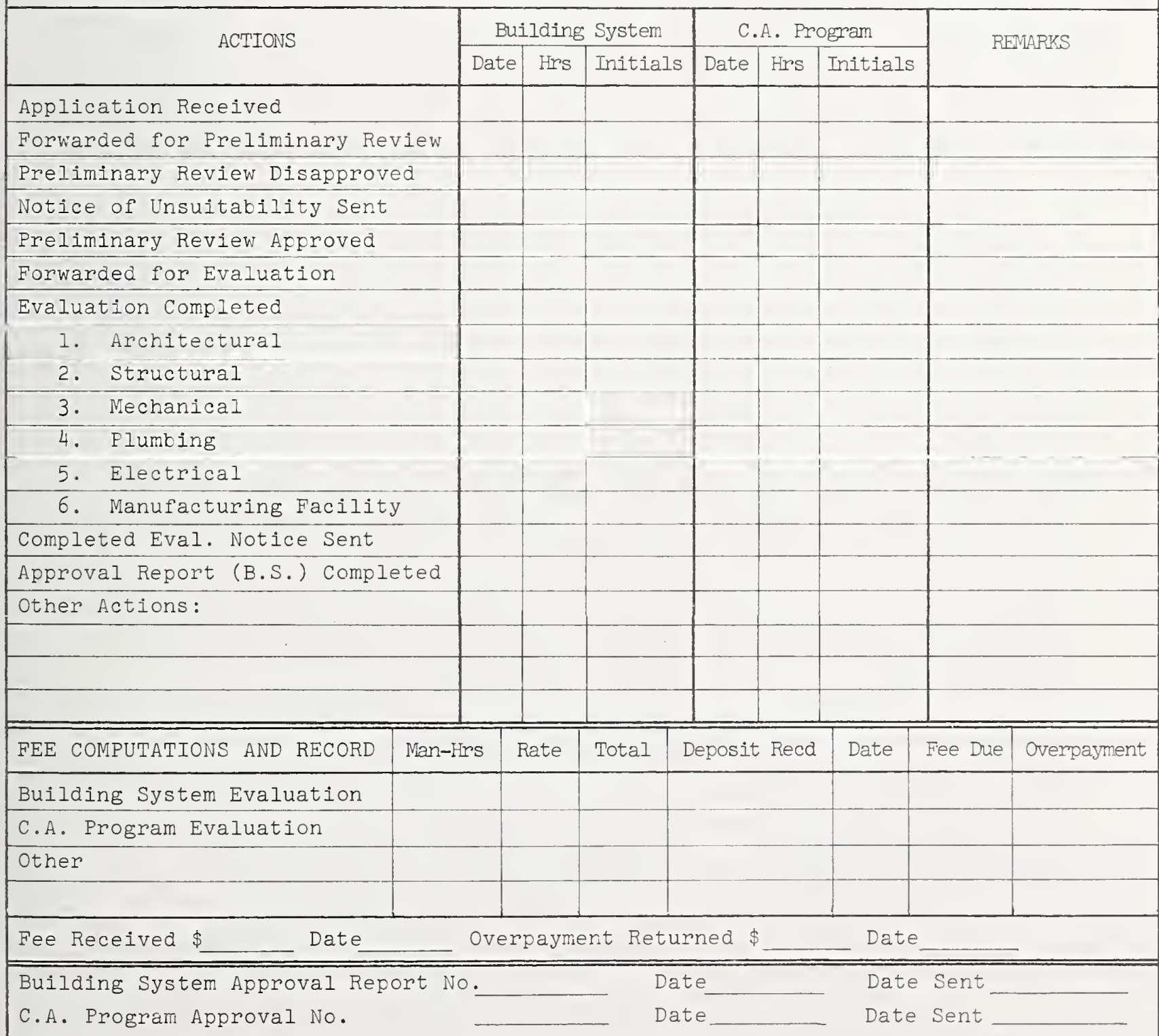




\section{.}




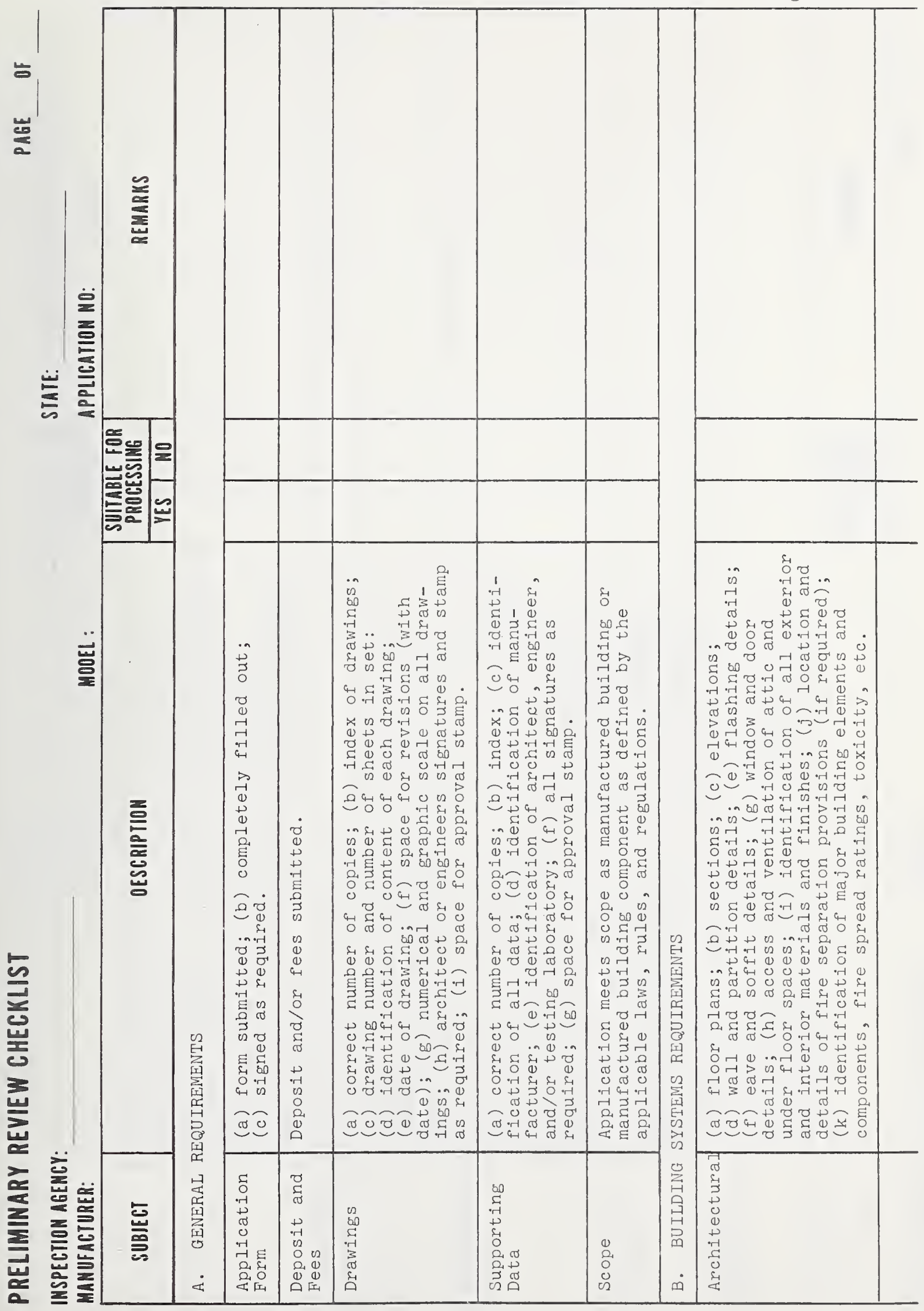




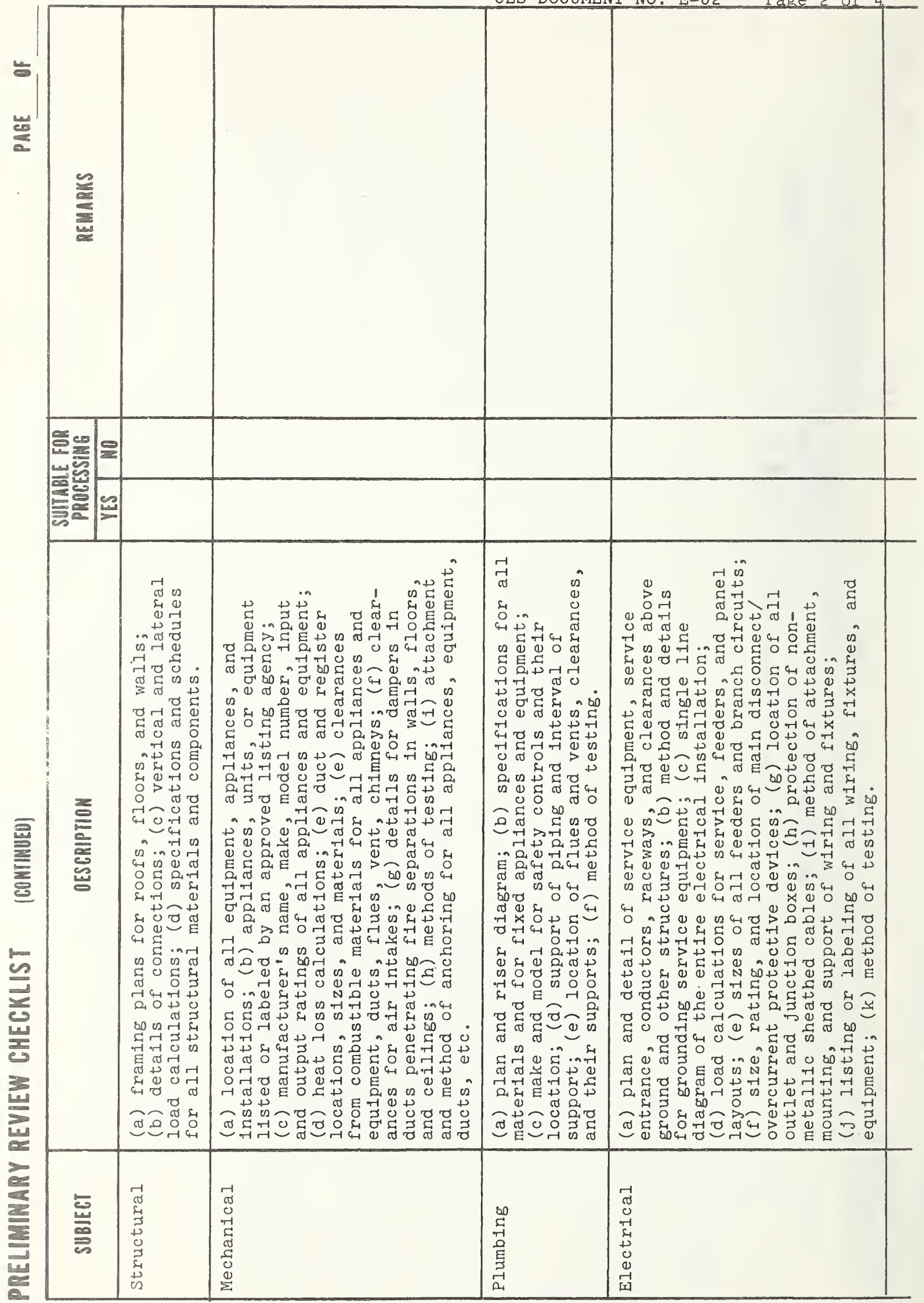




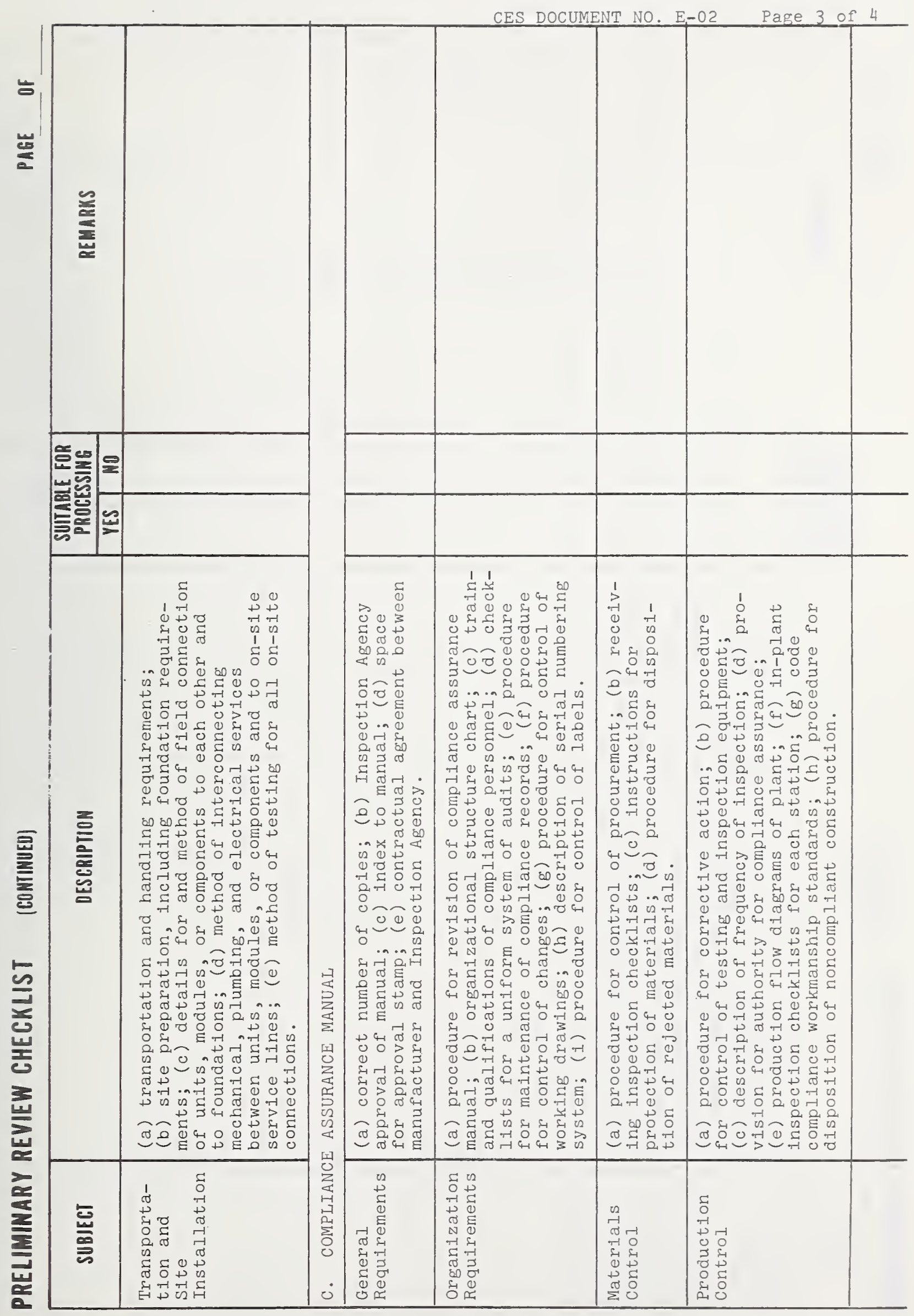




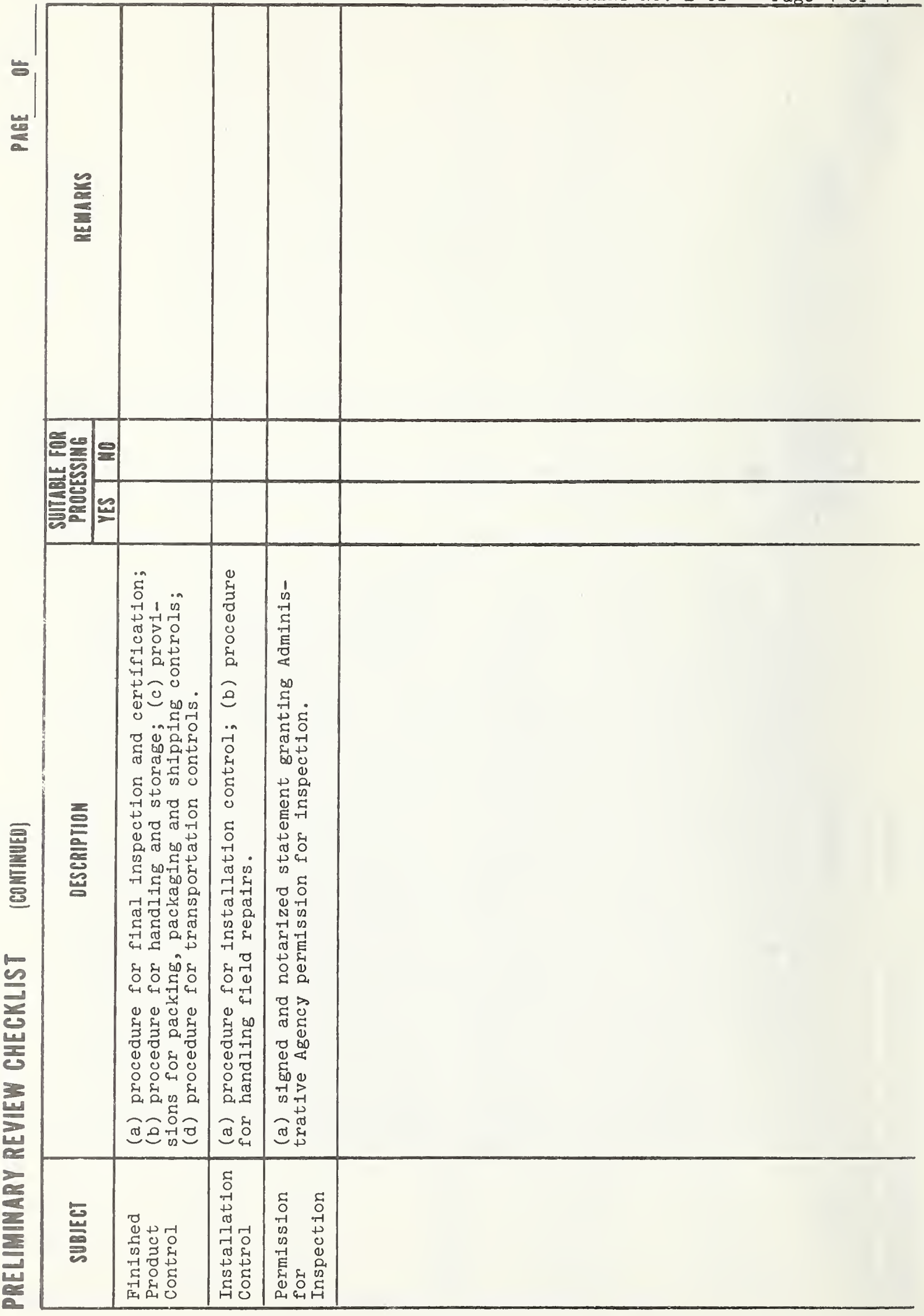


STATE OF

$\left[\begin{array}{c}\text { Name and Address of } \\ \text { Administrative Agency }\end{array}\right]$

$\left[\begin{array}{l}\text { Name of Manufacturer } \\ \text { Address }\end{array}\right]$

Date

RE: SUBMITTAL UNSUITABLE FOR PROCESSING

Dear Sir:

Our preliminary review of your submission of the following application(s) for the approval of

$\square$ Building System - Application No.

$\square$ C.A. Program - Application No.

indicates that your submittals are unsuitable for processing due to following reasons:

Attachments :

$\square$ Preliminary Review Checklist

$\square$ Documents Returned $\square$ plans $\square$ specs $\square$ calculations $\square$ test data $\square$ c.A. Manual $\square$ other

Sincerely,

Signature of Agency Official

Name and Title 
CES DOCUMENT NO. E-04 Page 1 of 8

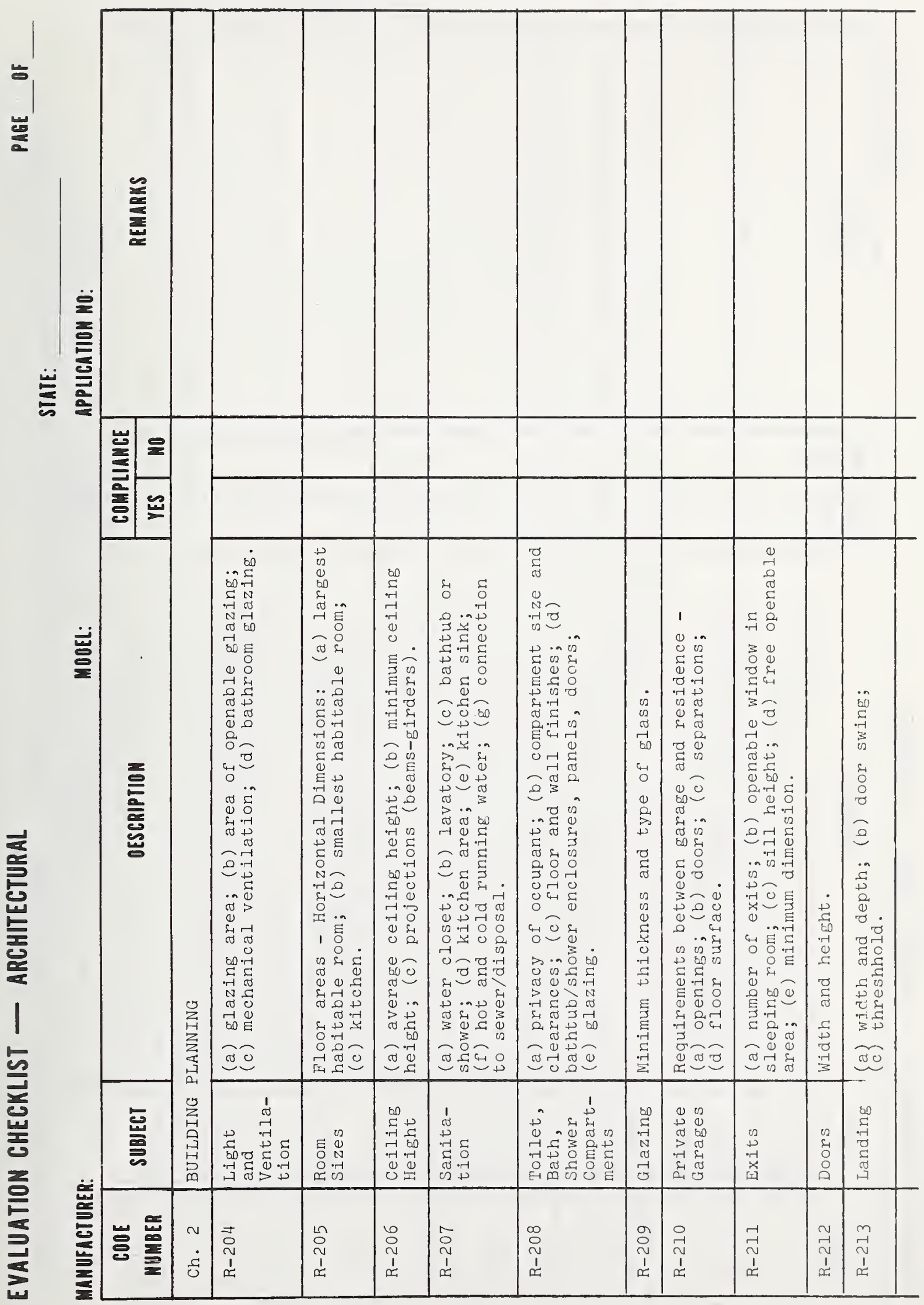




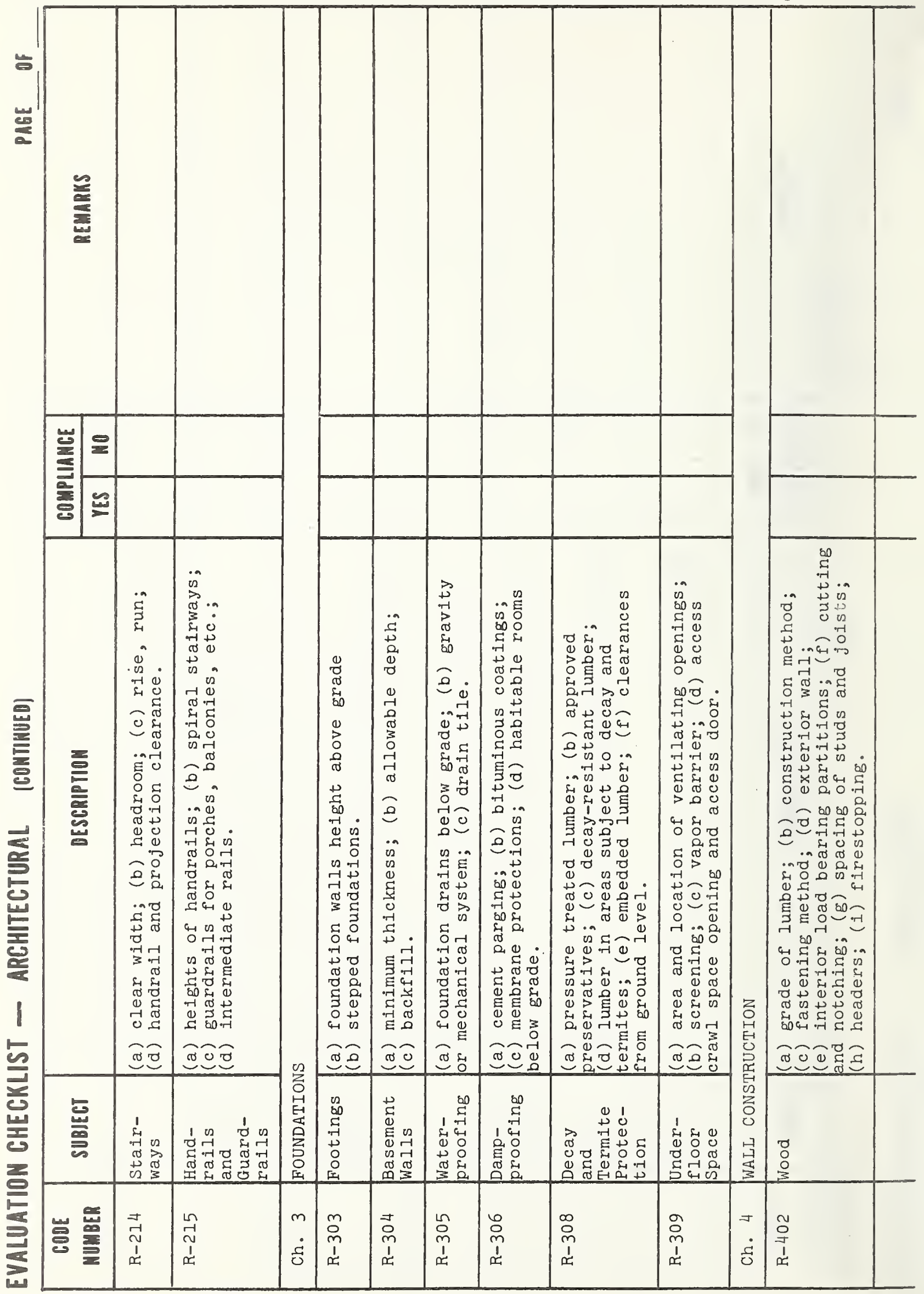




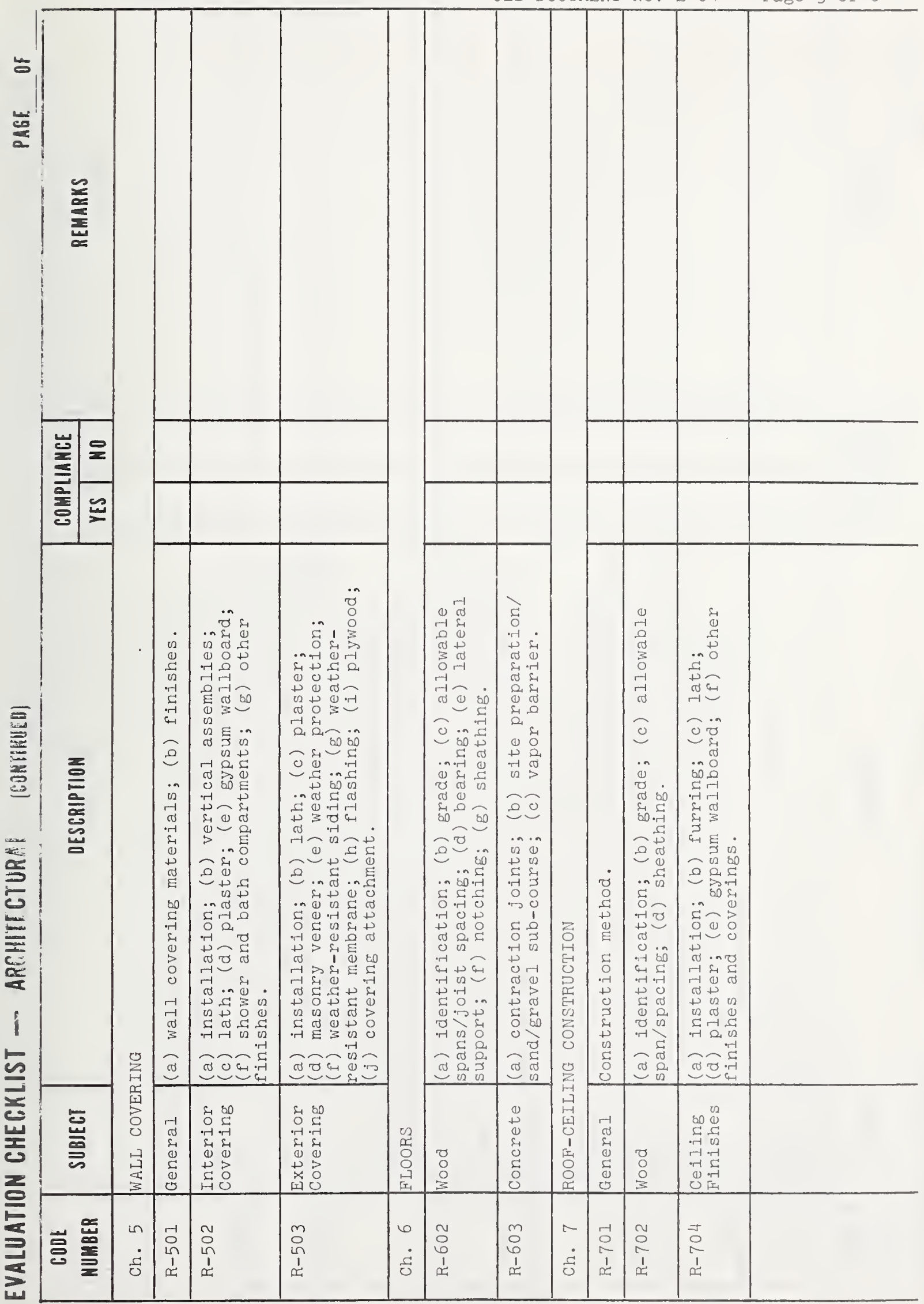




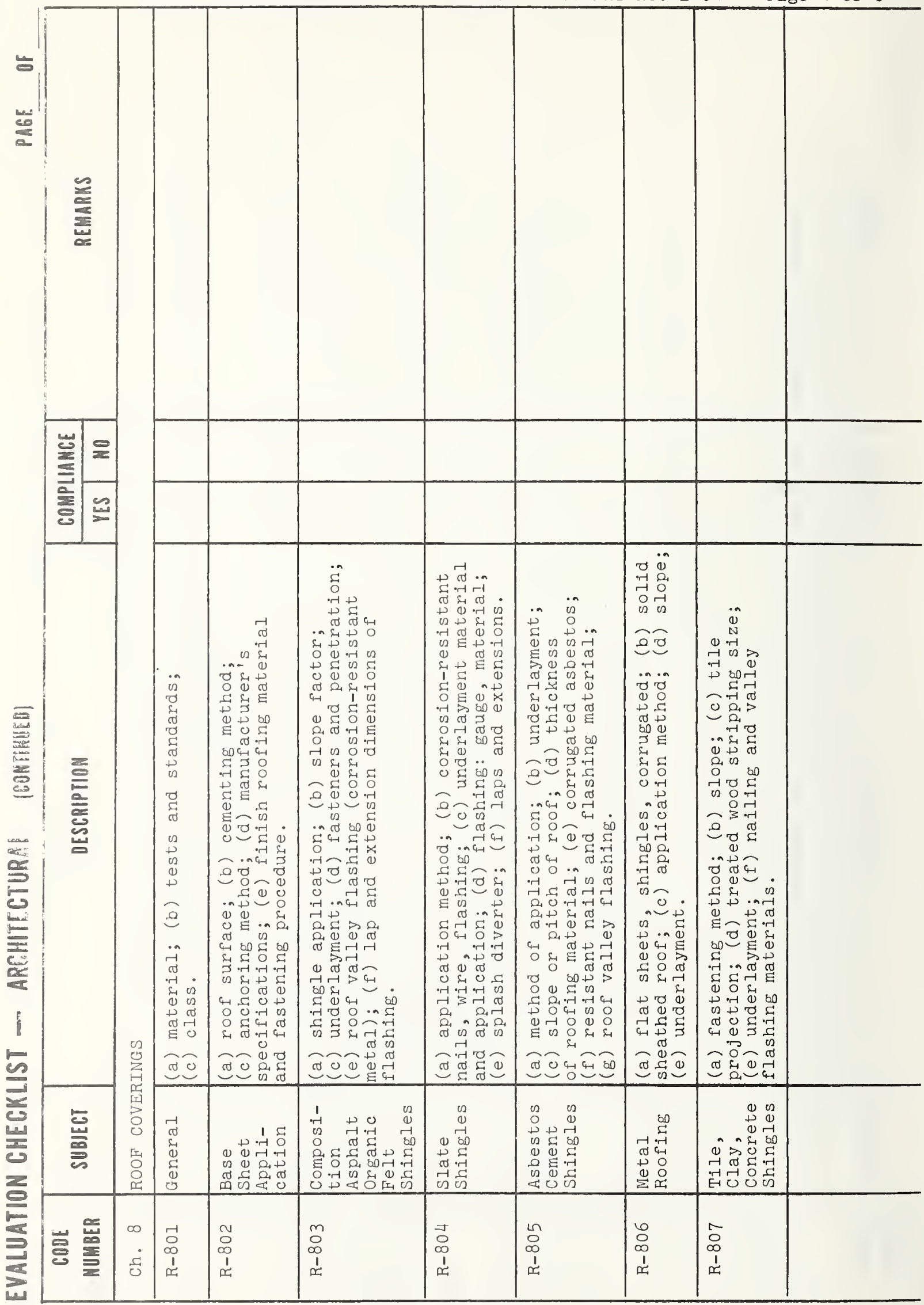




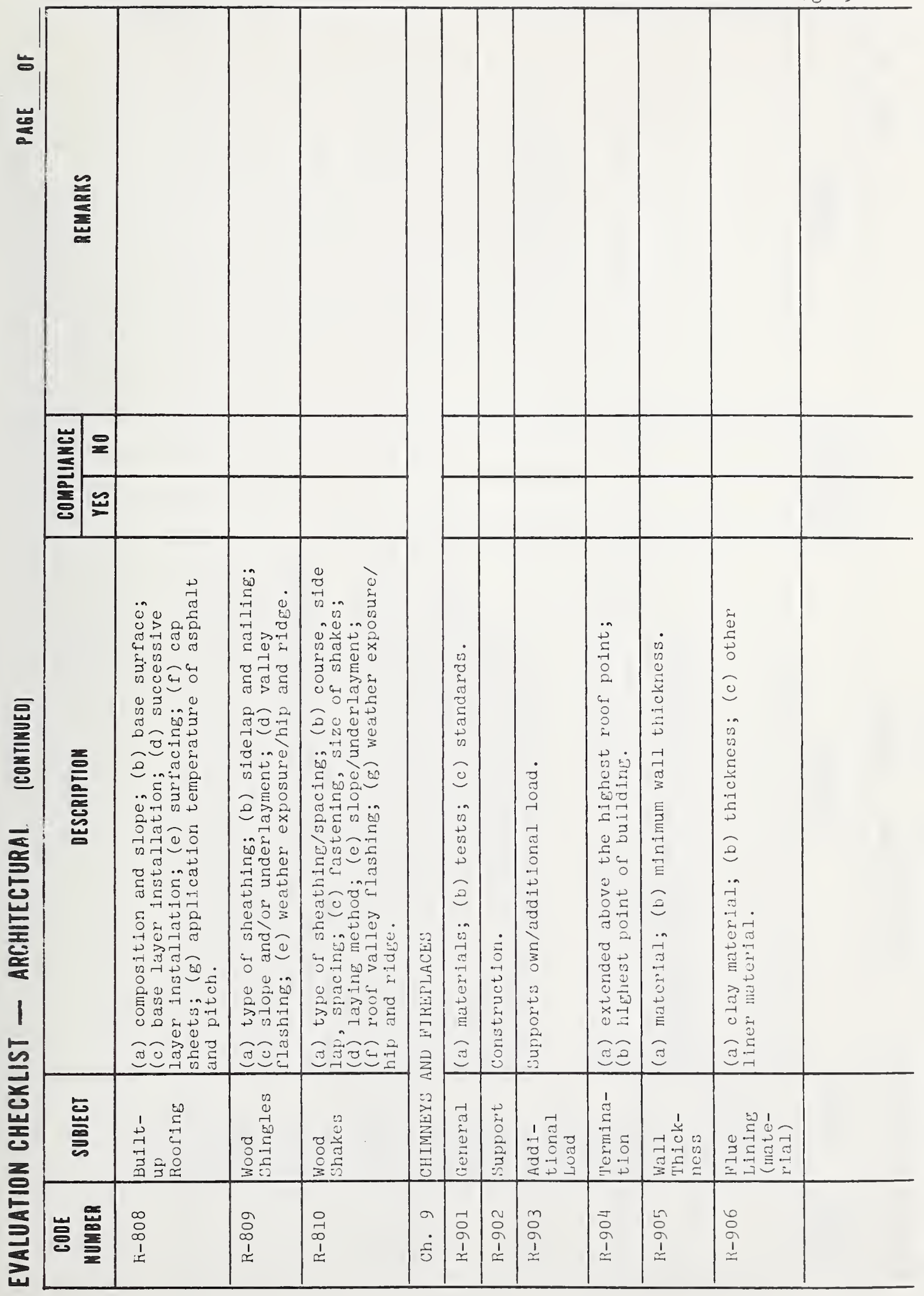



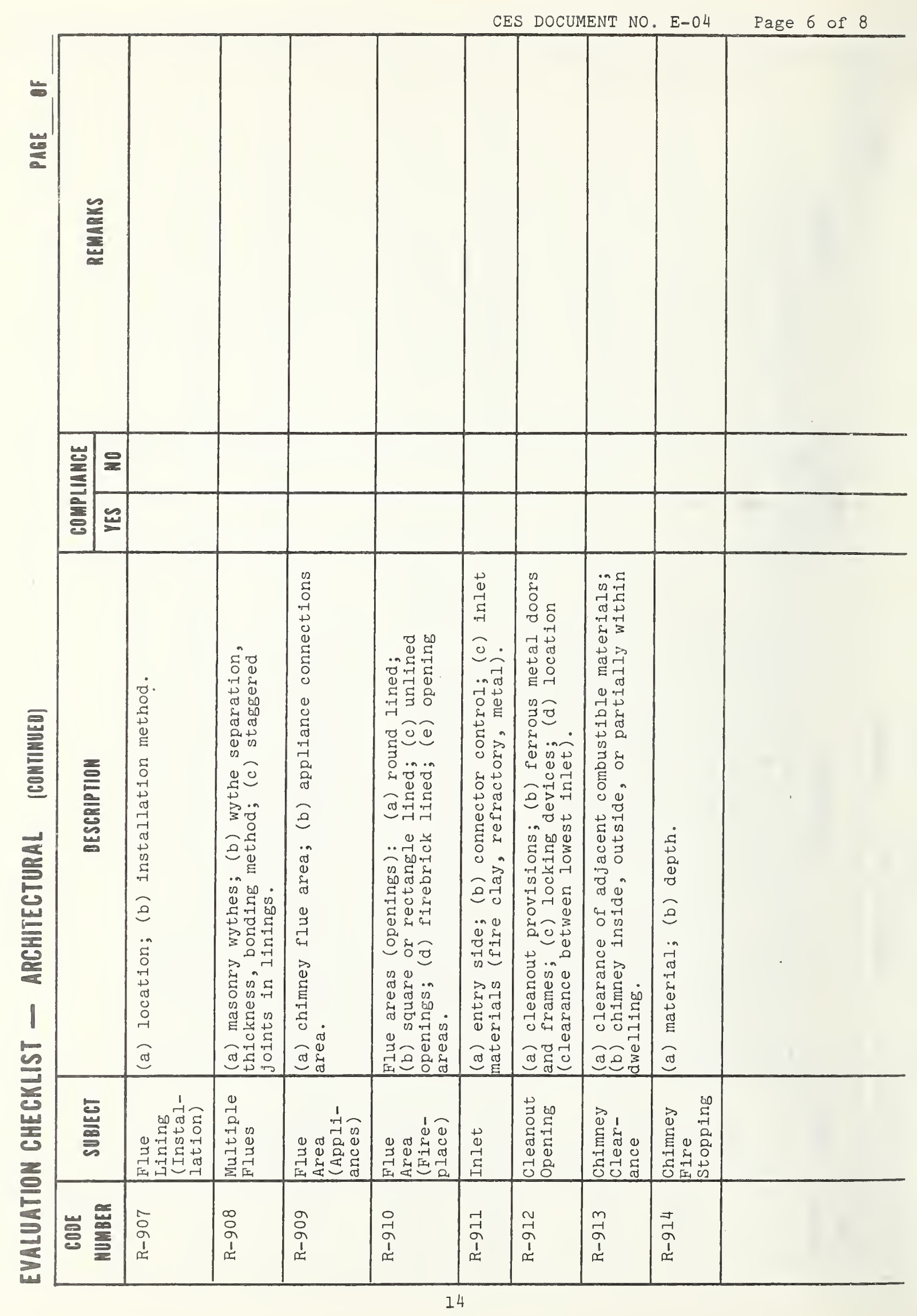


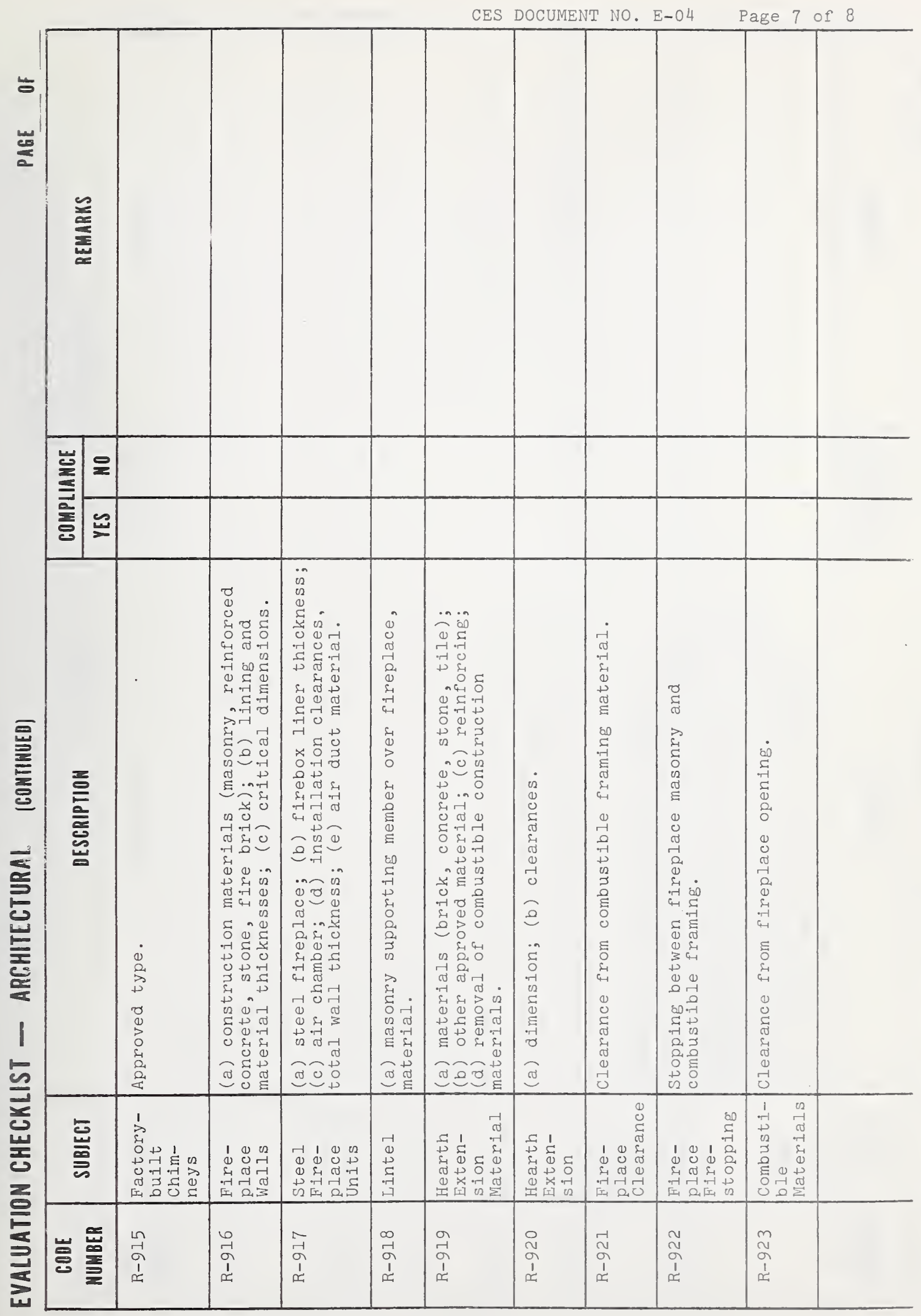




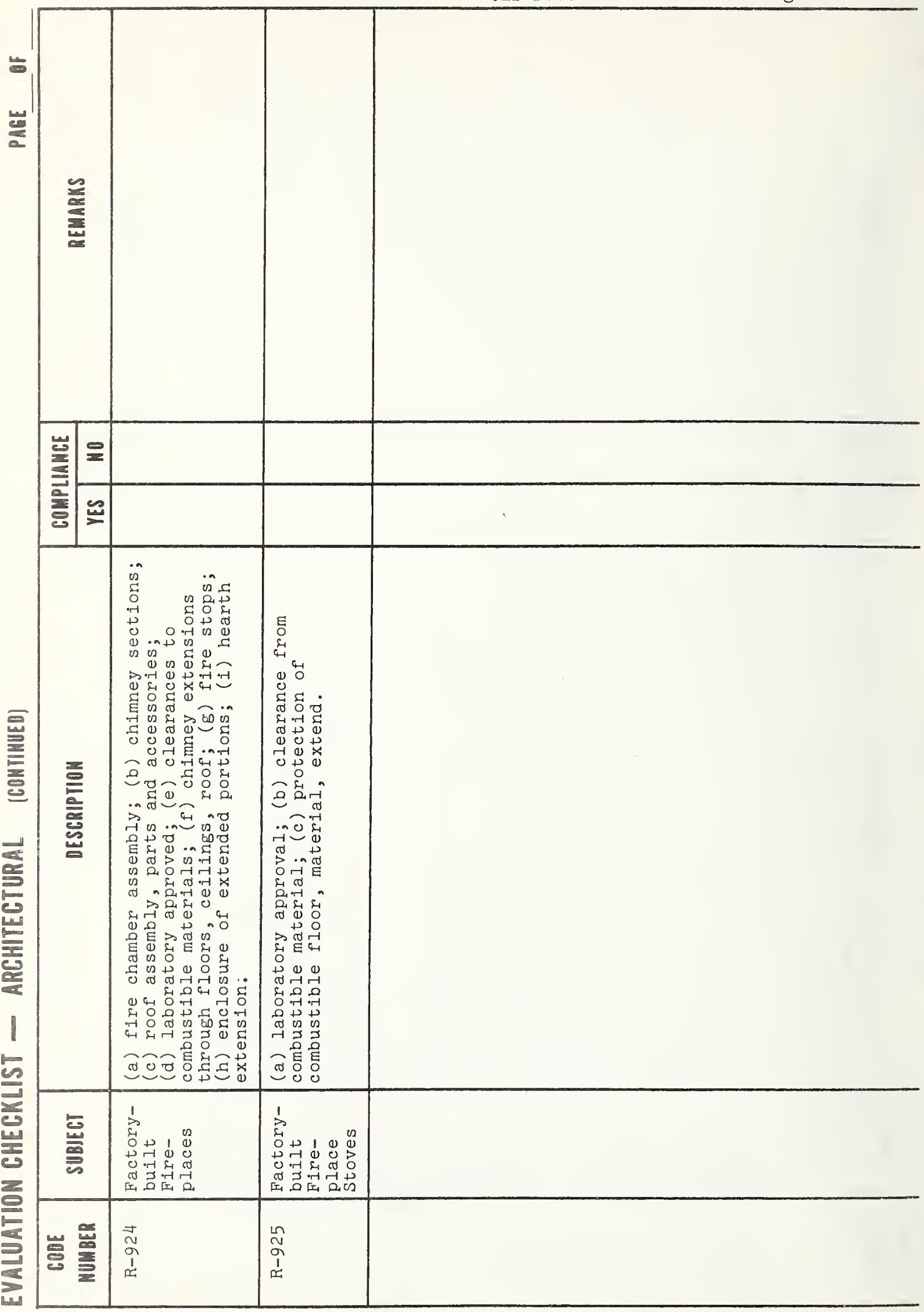




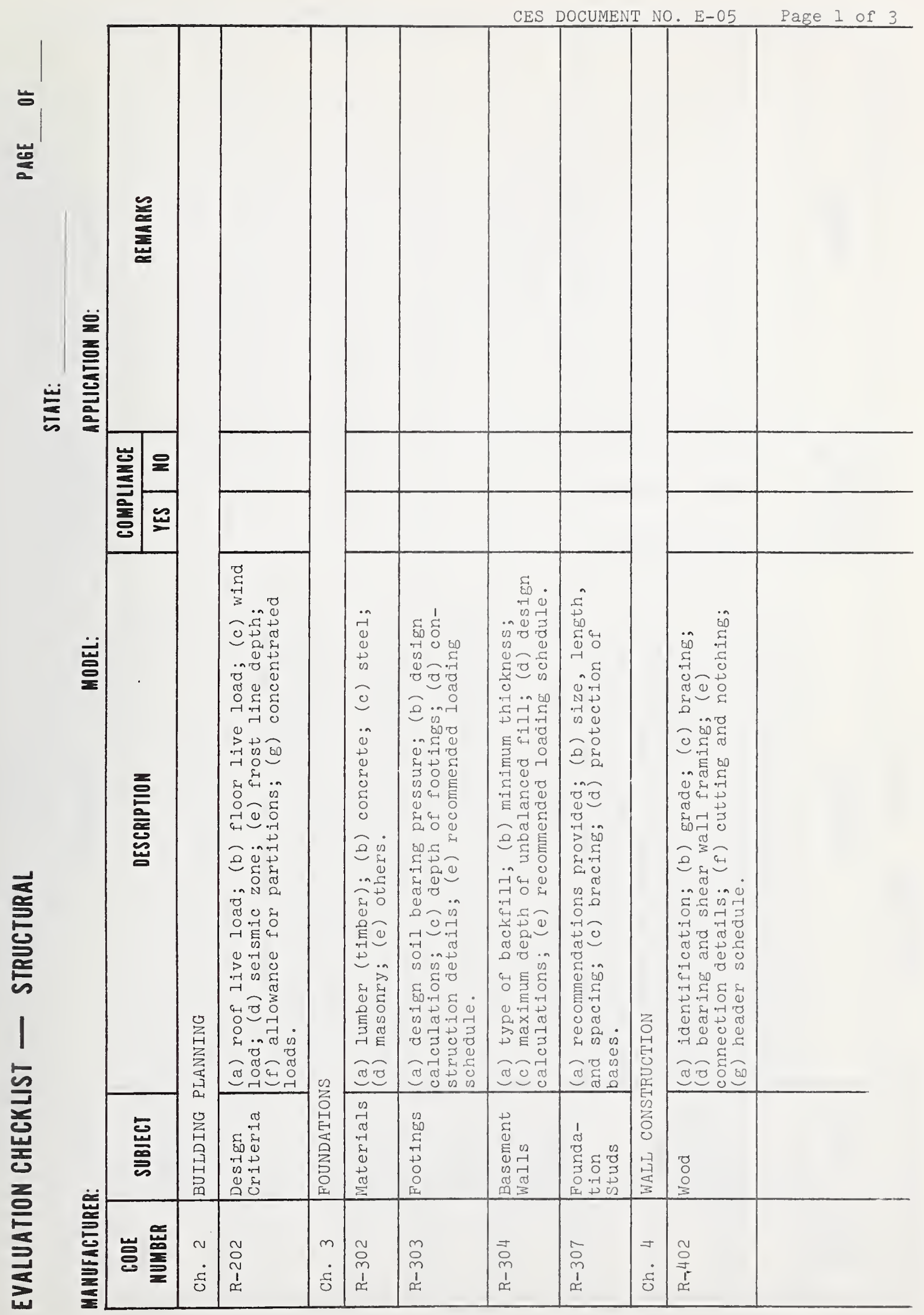




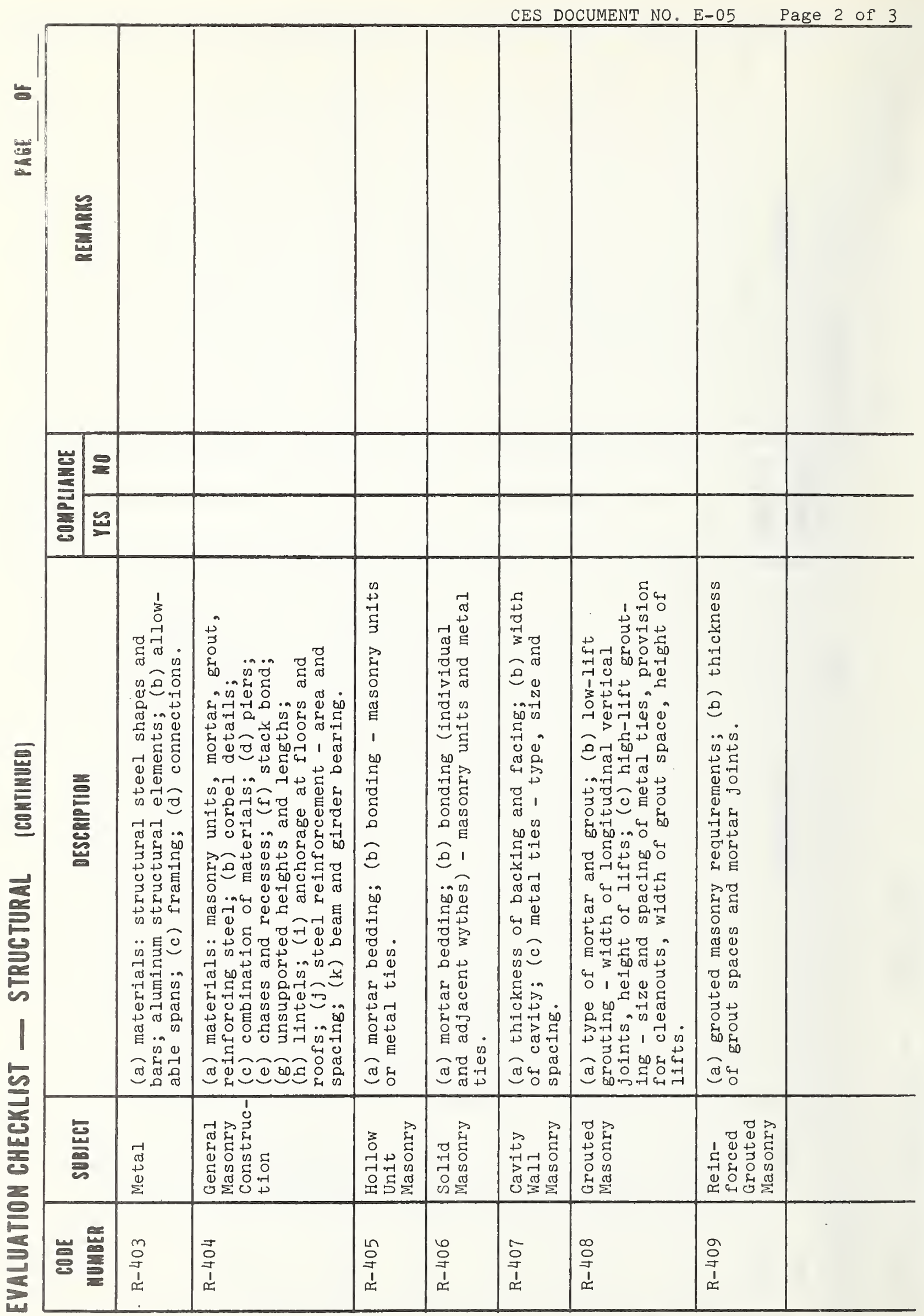




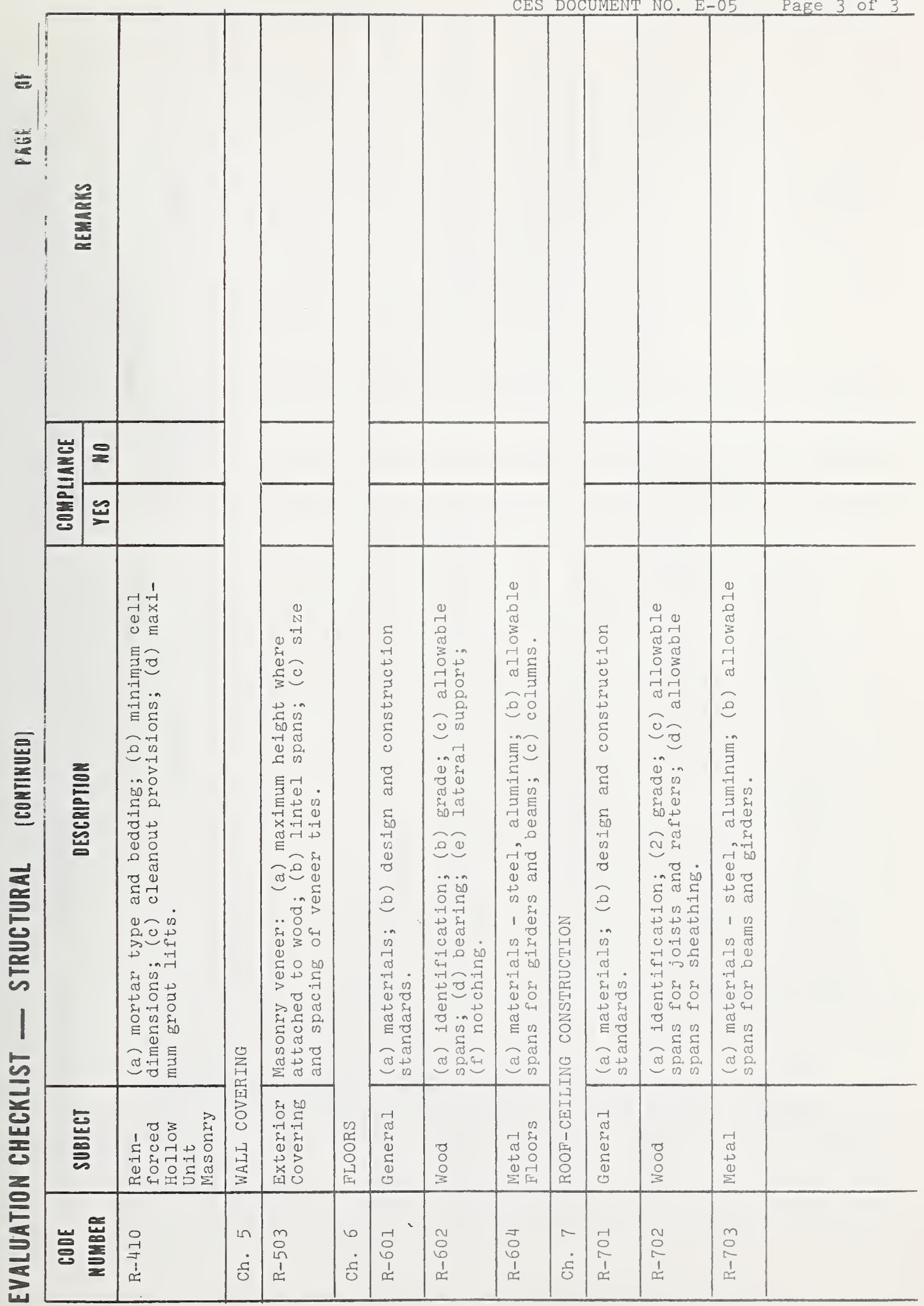





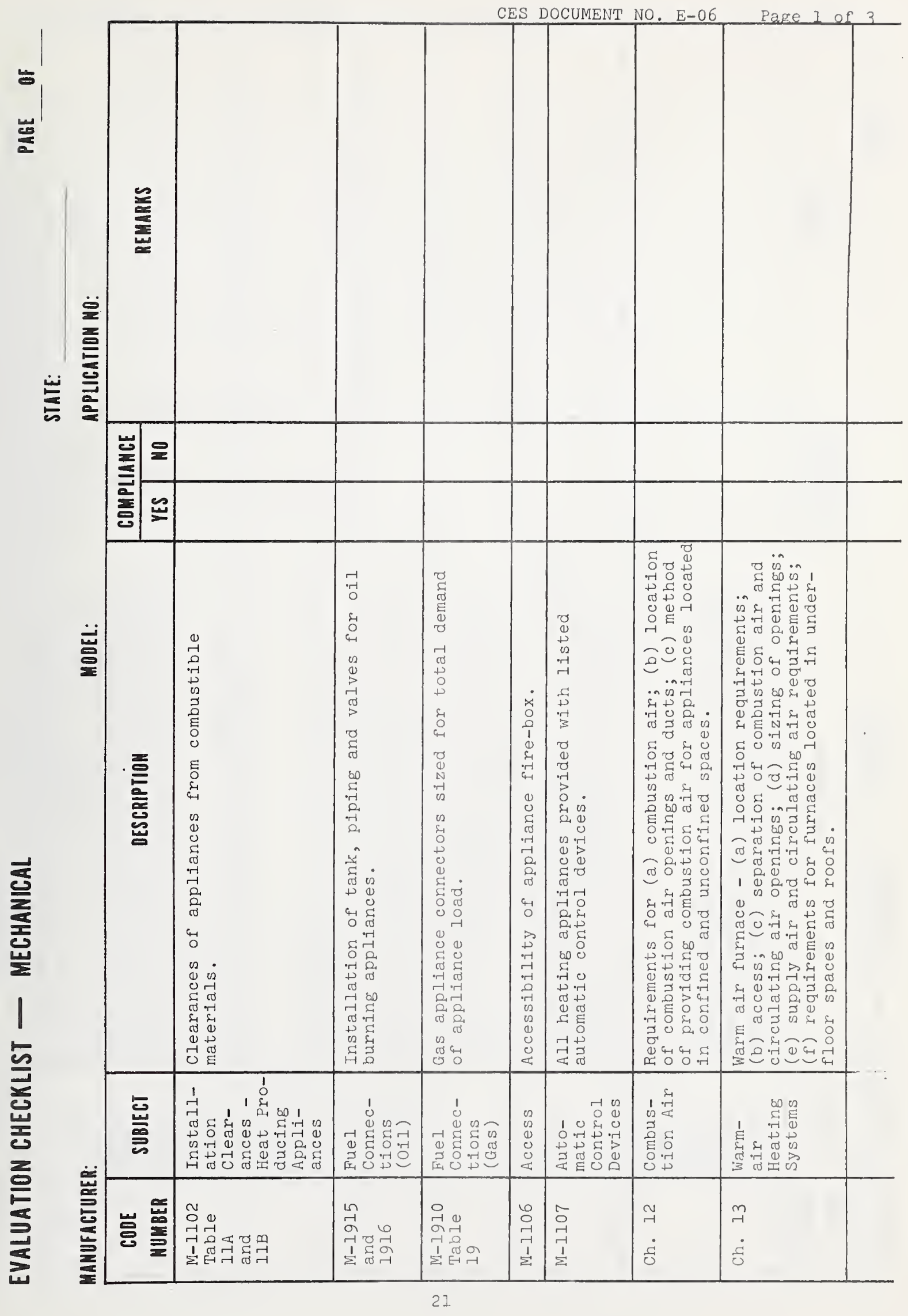




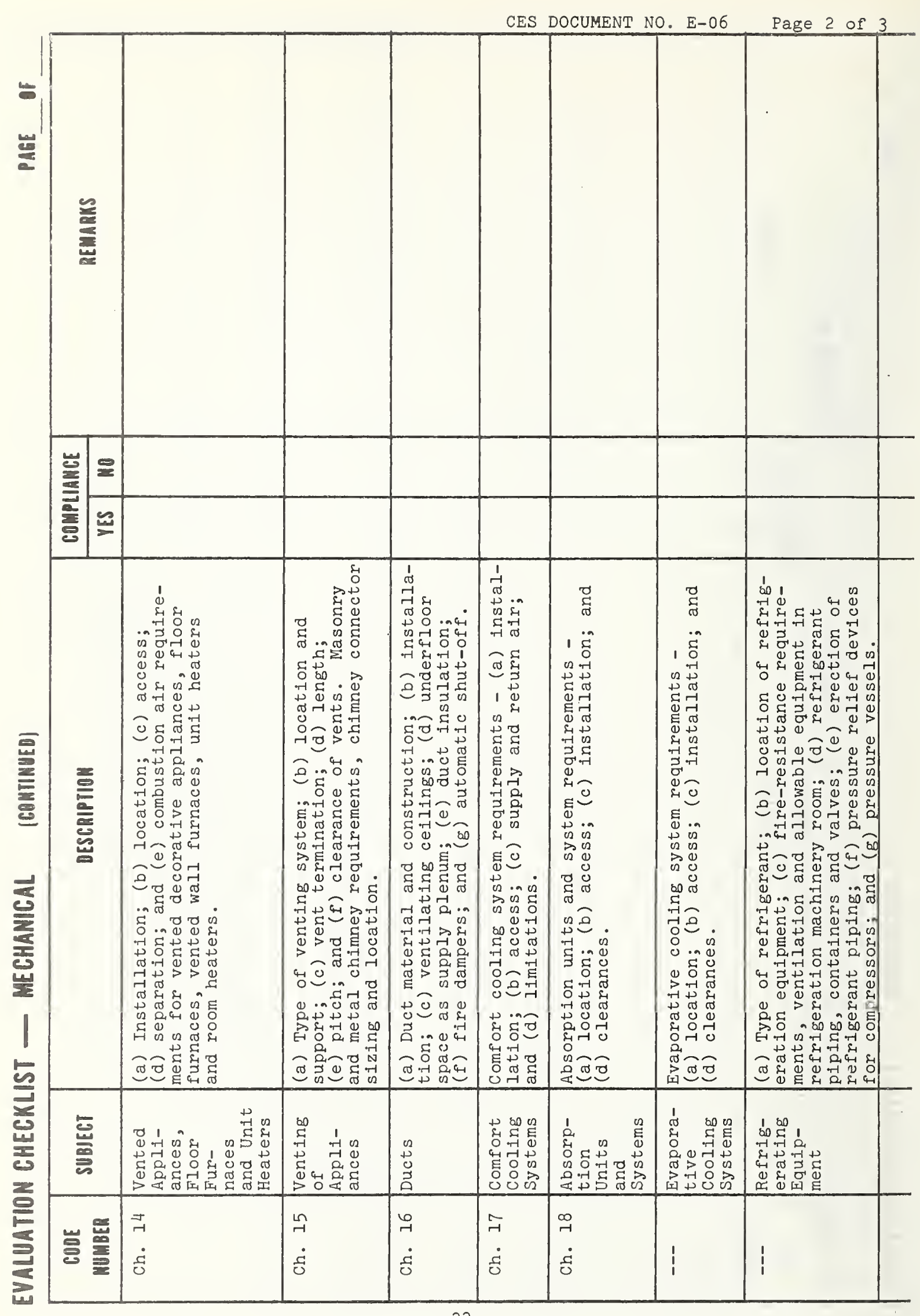




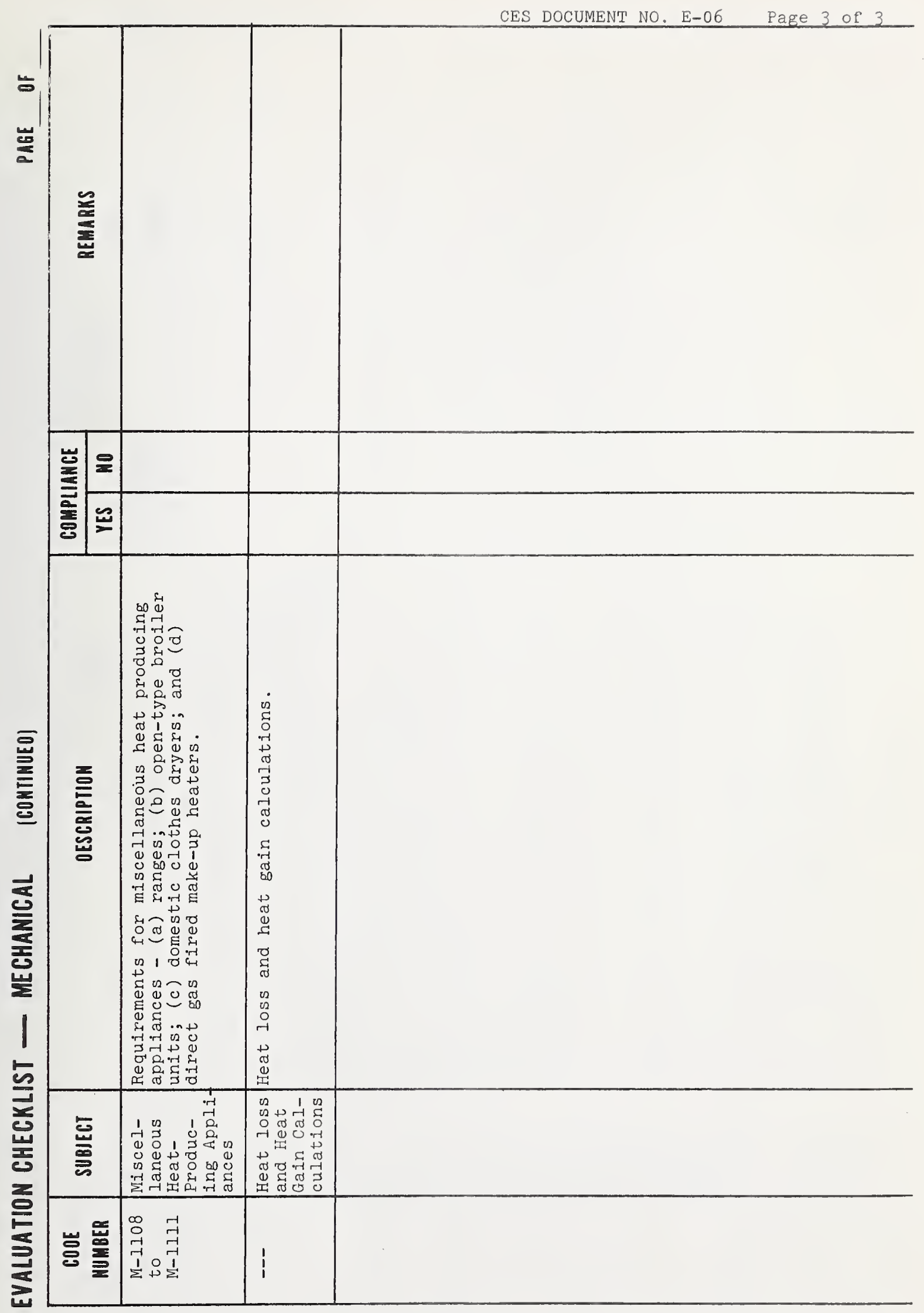





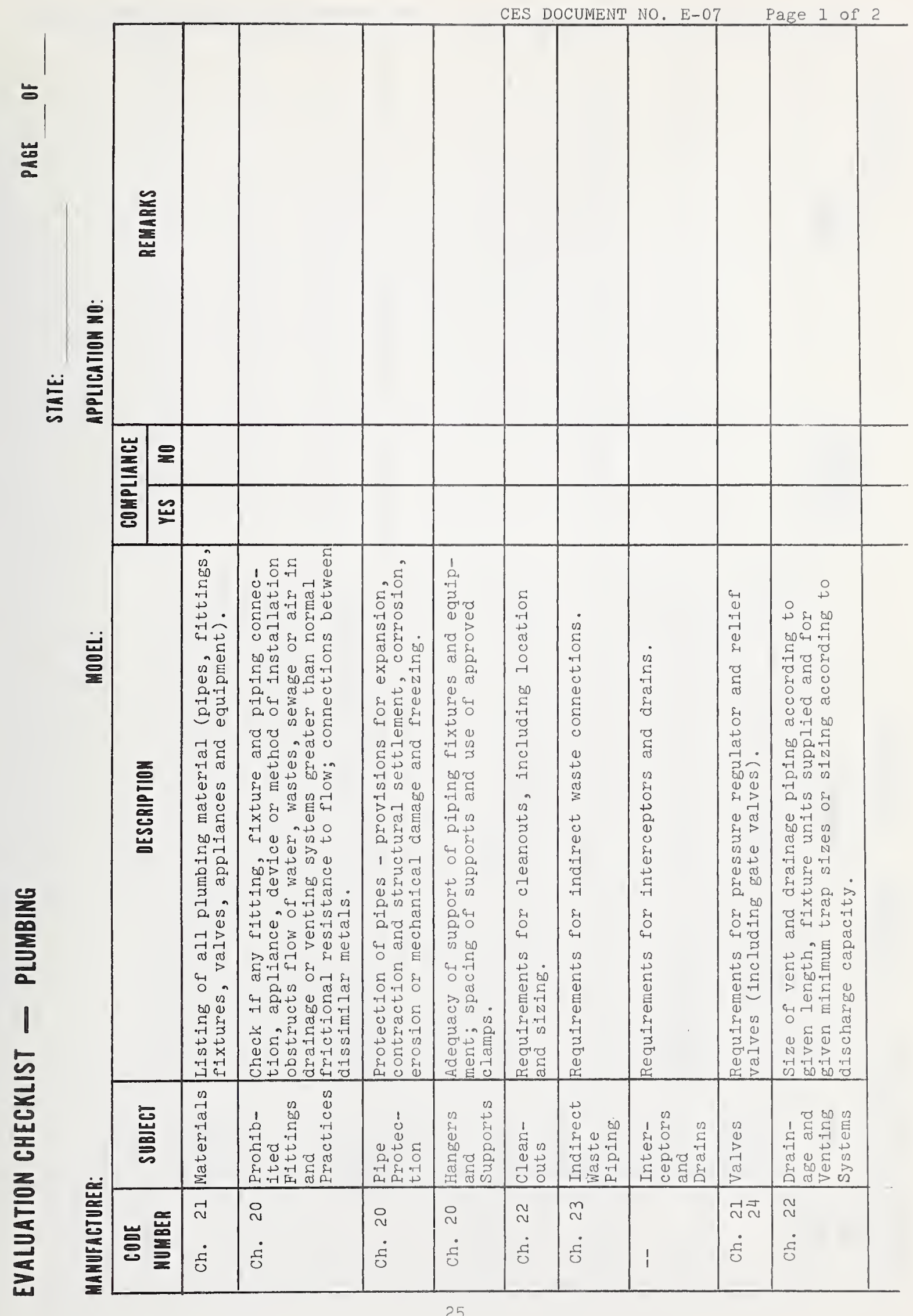




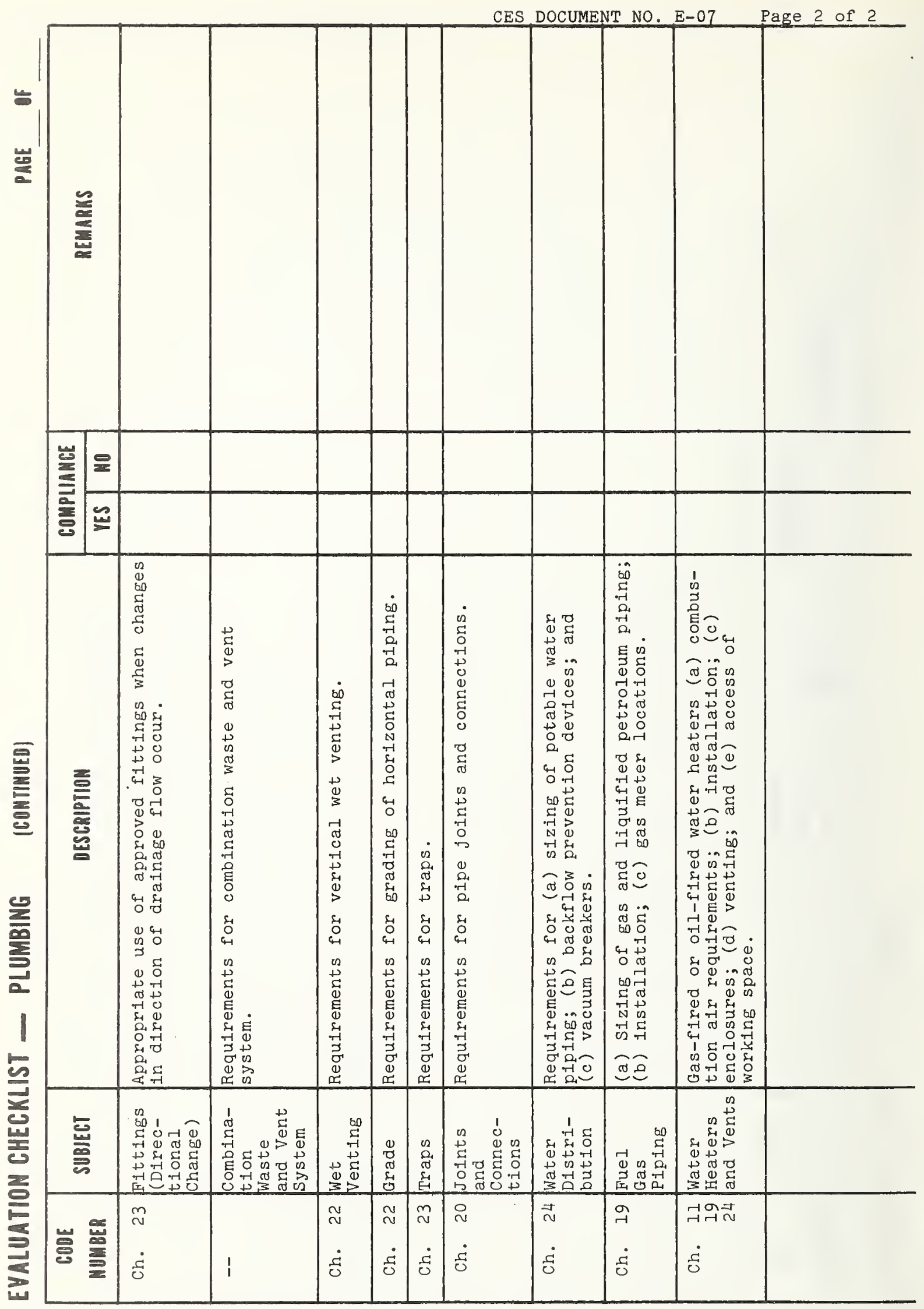




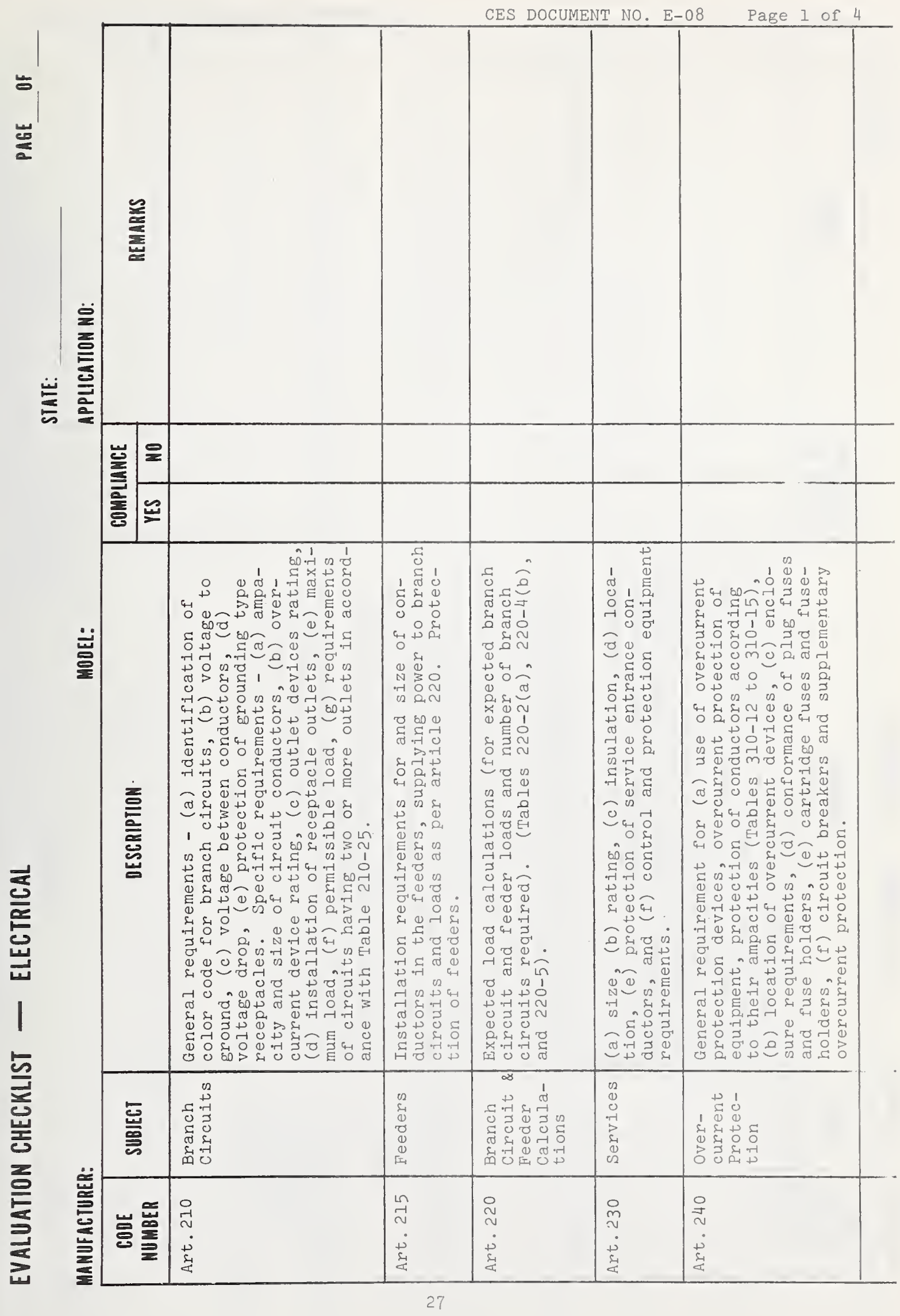




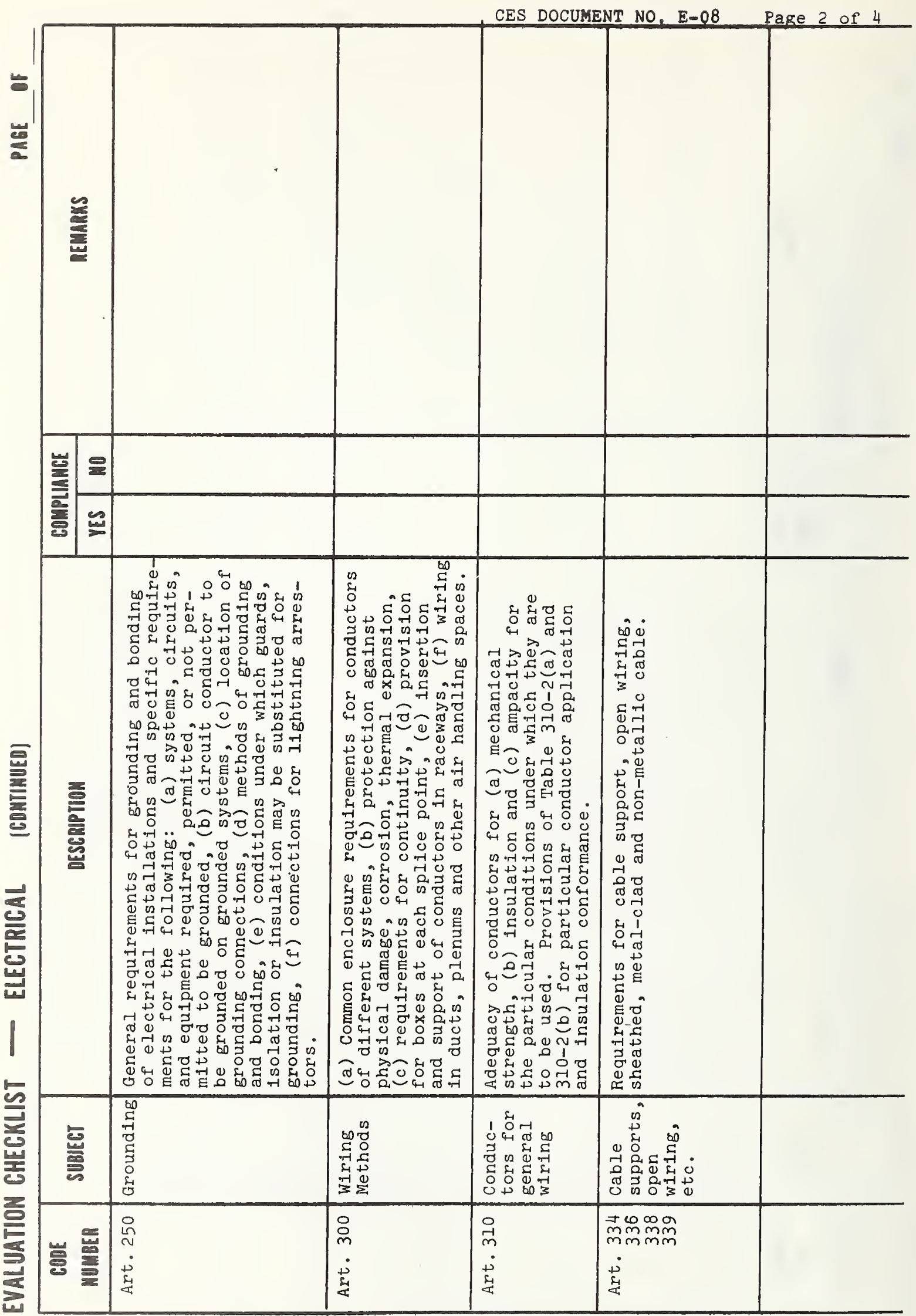




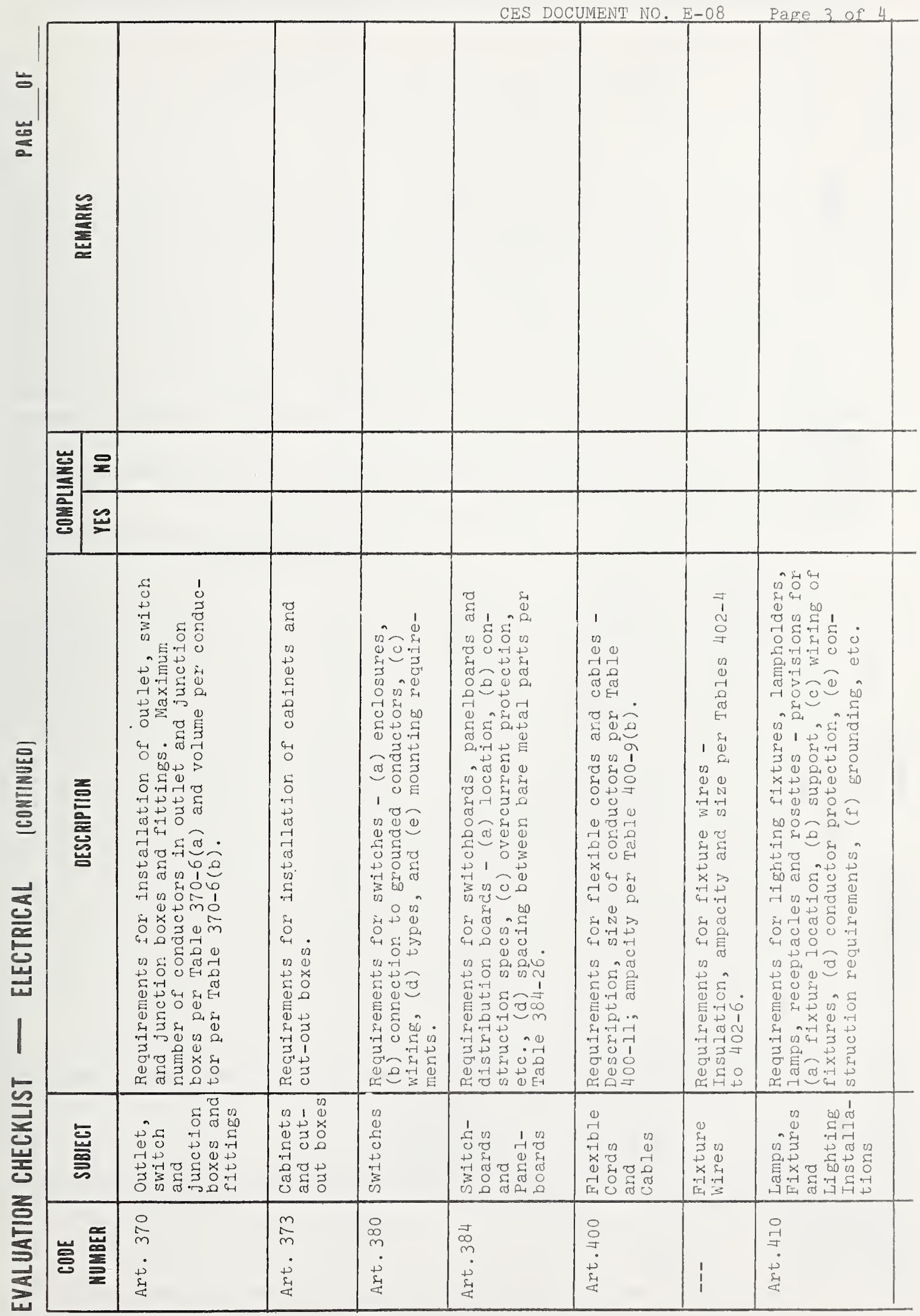




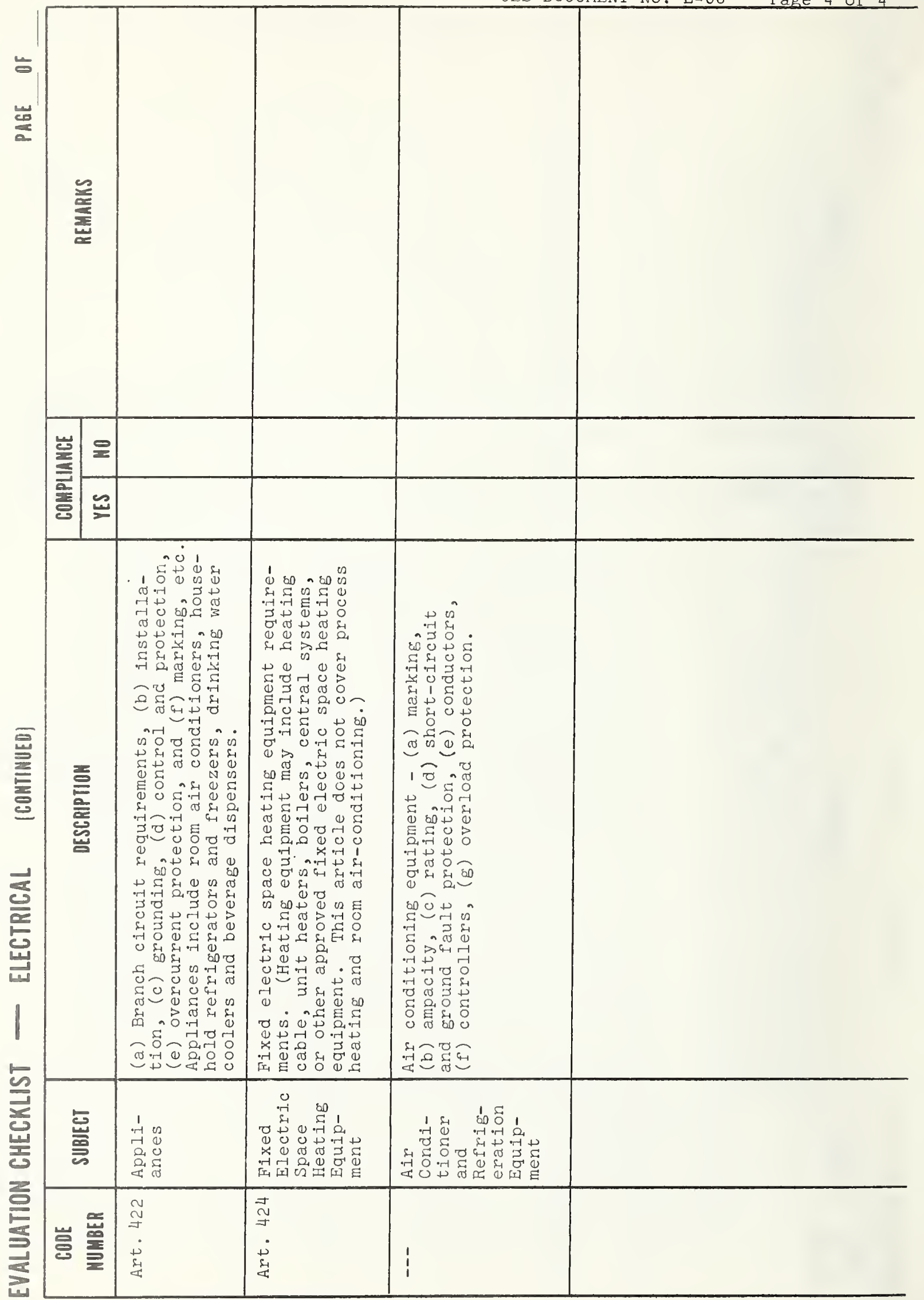




\section{a. Certification}

Some form of certification exists today for many building products. The purpose of such certification is to assure the compliance of the product to some code or standard of safety and performance. The certification programs are either: (1) established and administered by independent organizations such as Underwriters' Laboratories; (2) established by a trade association but administered by an independent organization such as the window certification program of the Architectural Aluminum Manufacturer's Association, administered by Electrical Testing Laboratories, Inc.; (3) both established and administered by a trade association such as the program sponsored and administered by the American Plywood Association; or (4) administered and enforced by a single manufacturer (self-certification). Some certification programs are based on a single test or evaluation of a prototype, some are based on periodic retesting or re-evaluation of the product, and some finally are based on tests and on a continuing surveillance of the manufacturing process to assure not only that the design of the product complies to a prescribed code or standard, but also that actual production units meet such code or standard.

From the above discussion it is evident that the degree of confidence that the evaluator can place in the certification of a specific product depends on the type of certification process associated with the product. Accordingly, the certification information to be submitted to the evaluator for the determination of the product's compliance with a specific code or standard should include the following data:

\section{Identification of product}

2. Name of agency or organization that has established the certification program.

3. Name of agency or organization that administers the program.

4. Code or standard that forms the technical basis for the certification.

5. Type of evaluation method used (testing, analysis).

6. Number of specimens tested or evaluated.

7. Sampling techniques and identification of person conducting the sampling.

8. Frequency of follow-up tests.

9. Brief description of surveillance activity to assure uniformity of production quality.

10. Limitations, if any, of the certification.

Although all the above factors can influence the confidence to be placed ir any particular certification program, it is recognized that some programs have been found so reliable that they are nationally recognized. In such instances Administrative Agencies do not normally require the submission of all the above information. It should also be recognized that the certification programs themselves depend largely on the characteristics of the product, particularly its complexity. Accordingly, both the evaluation of and the submission requirements for certification documents will depend on the individual product. It would serve both the Administrative Agency 
and the manufacturer if the agency would prepare a list of those products and certification programs for which not all the above information need to be submitted.

\section{b. Test Reports}

Tests on products, as used in this context, mean the testing of an individual product independent of any certification program. The purpose of such tests is the demonstration of the performance capabilities of a product related to specific or implied code or standards requirements. If the method of test is not given in the code or standard, the evaluation of the test report submission will have to include a determination of whether or not the test conditions simulate accurately the conditions to which the product will be subjected in service. Only after such a determination is an evaluation of the product's performance during the test meaningful. Where test methods are used that are promulgated by nationally accepted consensus standards organizations, such as ASTM, ANSI, etc., it need in general only be determined that such method truly applies to the specific product and intended use.

In recognition of the above, the test report submission requirements should include the following:

1. Identiflcation of the specimen tested (manufacture, type, model number, source of supply, etc.).

2. A detailed description or drawing of the physical characteristics of the specimen, including condition (age, repair, etc.).

3. Number of tests and sampling technique used in selection of specimens.

4. Identification of test method used (if a standard test method) or a detalled description of the test procedure, equipment, and instrumentation used.

5. Tabulation of numerical values assoclated with test, such loadings, voltage, etc., and corresponding result readings (e.g. deflections), giving the time scale involved.

6. Listing or Identification of any significant test conditions not indicated above (such as ambiant air temperature, humidity, etc.).

7. Date of test.

8. Name and address of testing organlzation or laboratory.

9. Signature of the laboratory's officer or authorized representative (generally a test engineer in charge who is a professional engineer), and date of signature. 


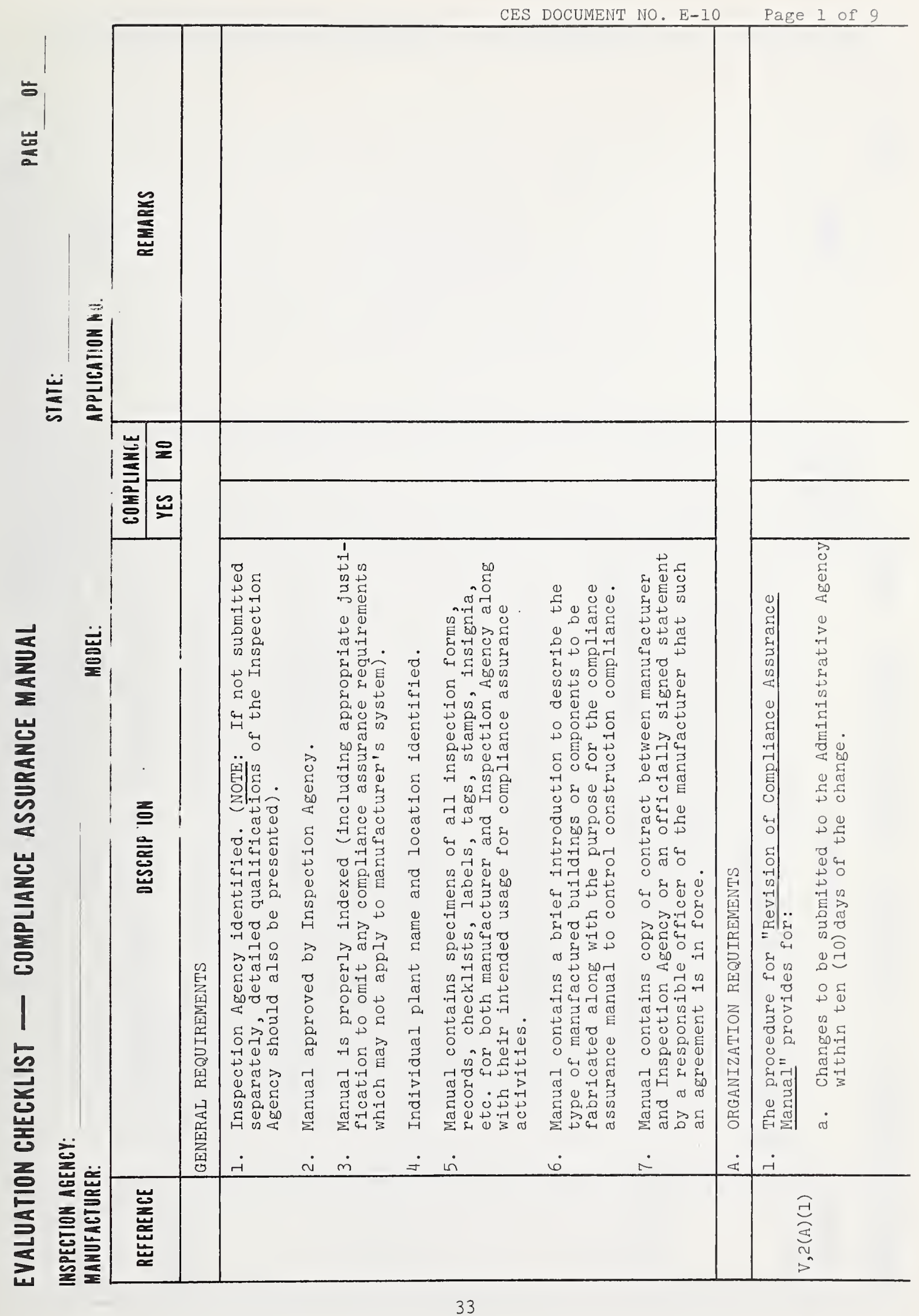




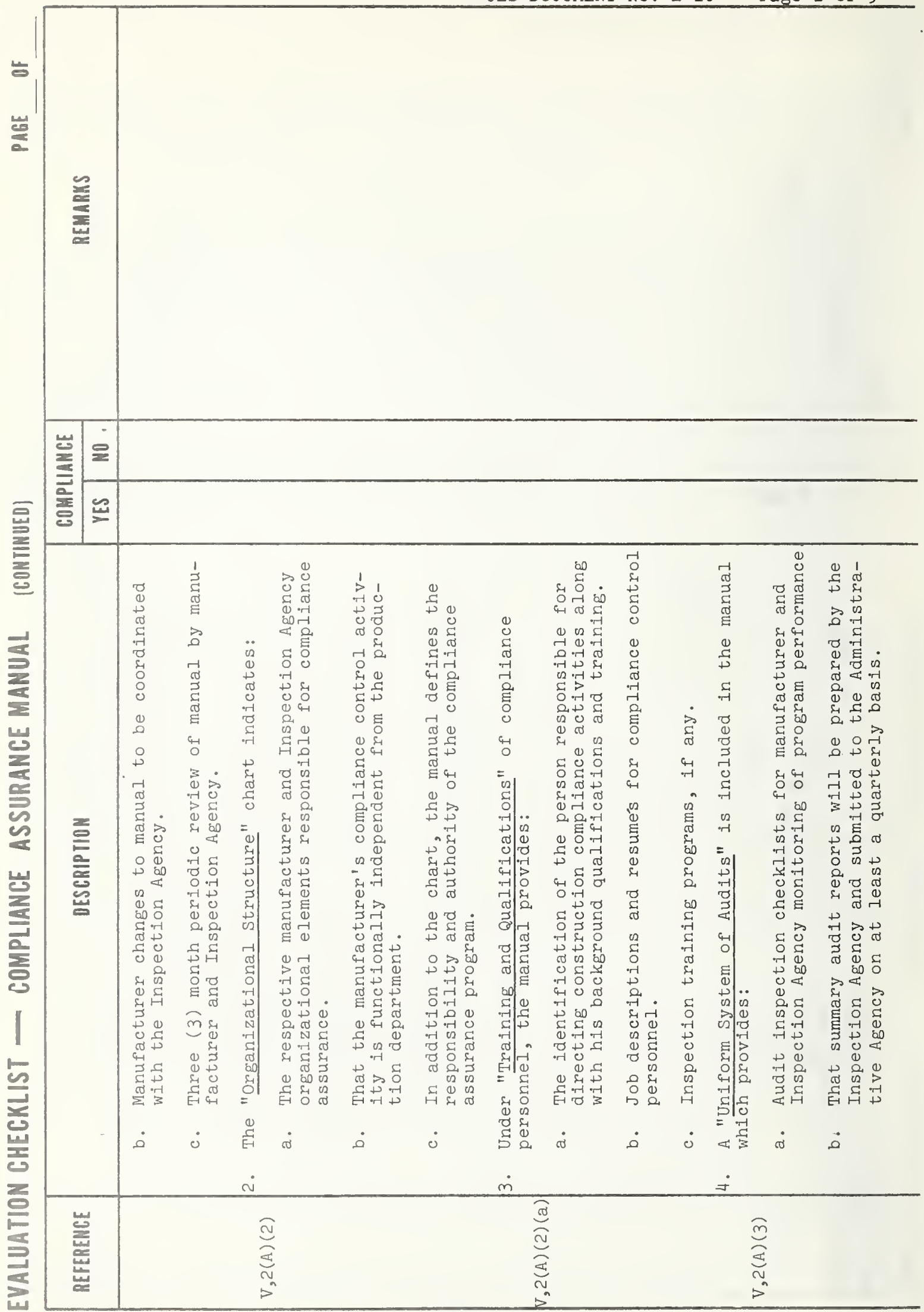




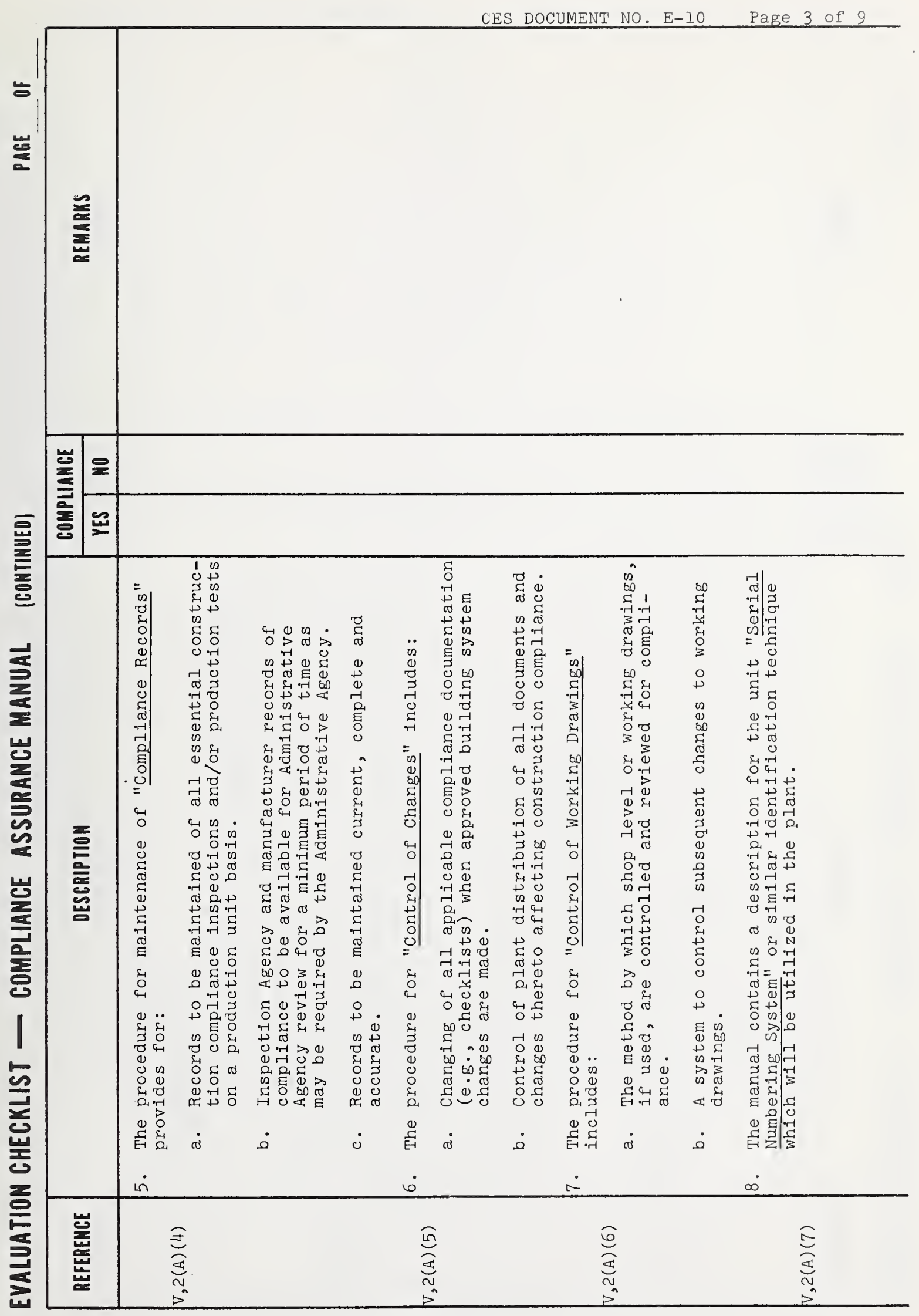




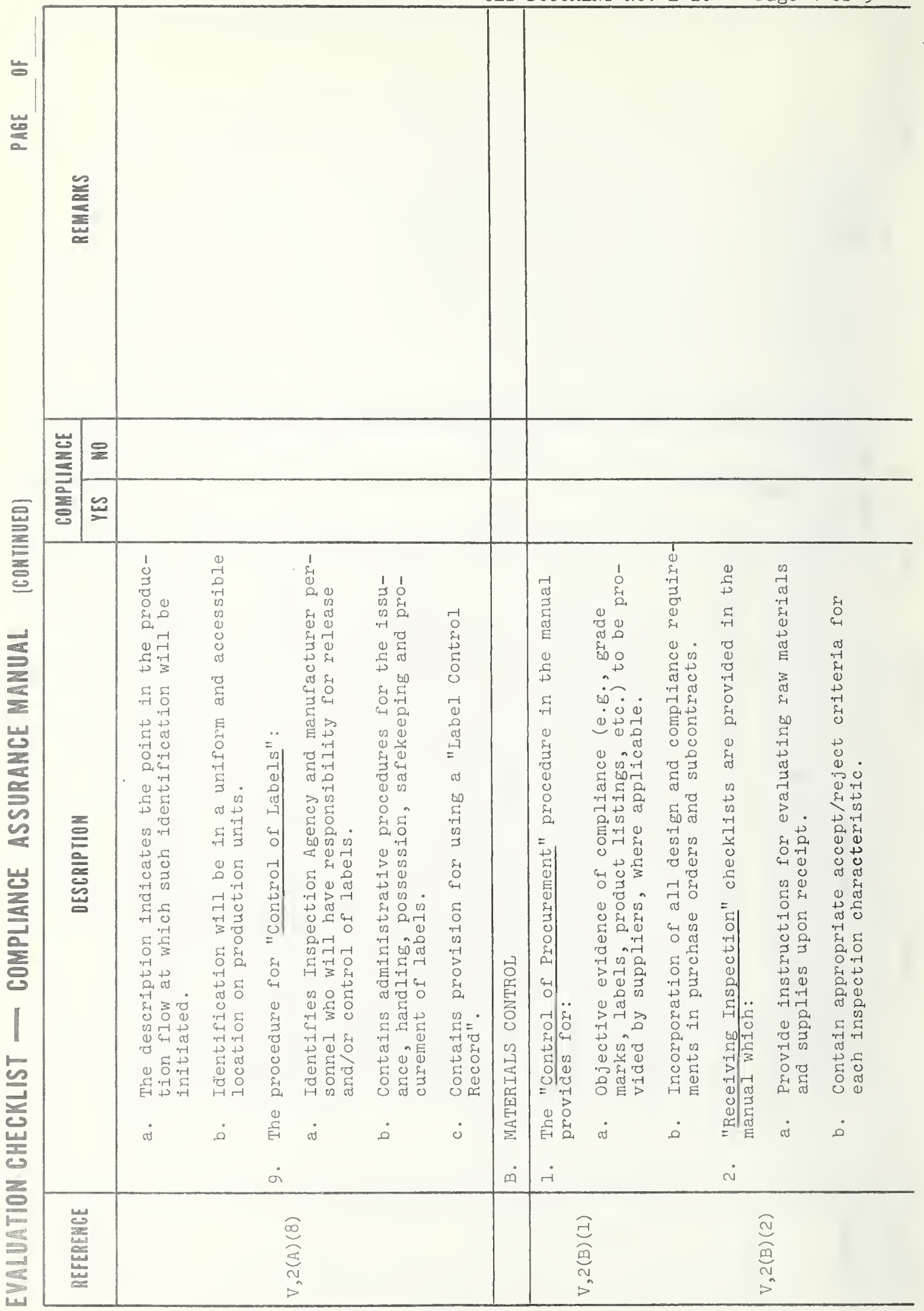


CES DOCUMENT NO. E-10 Page 5 of 9

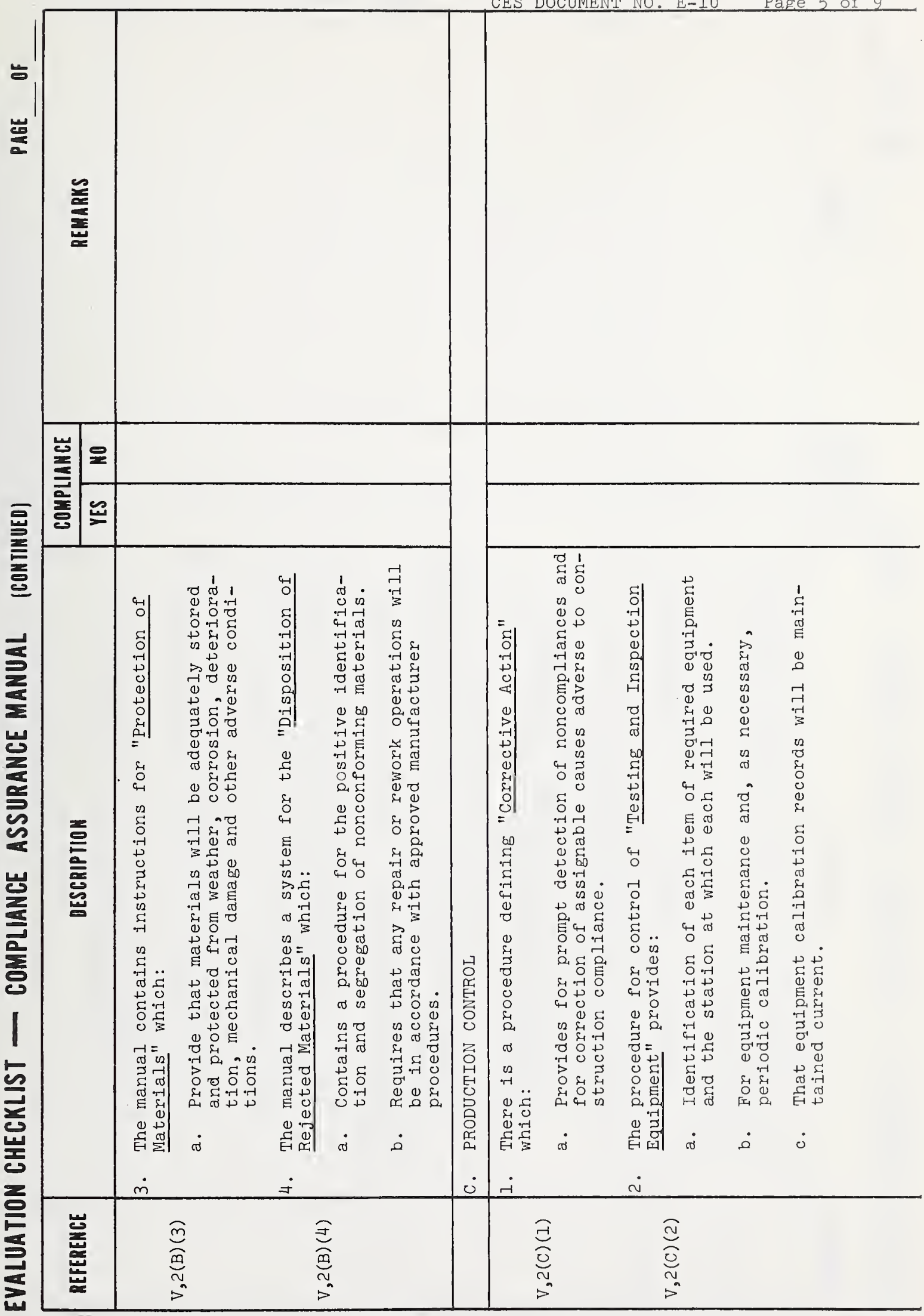




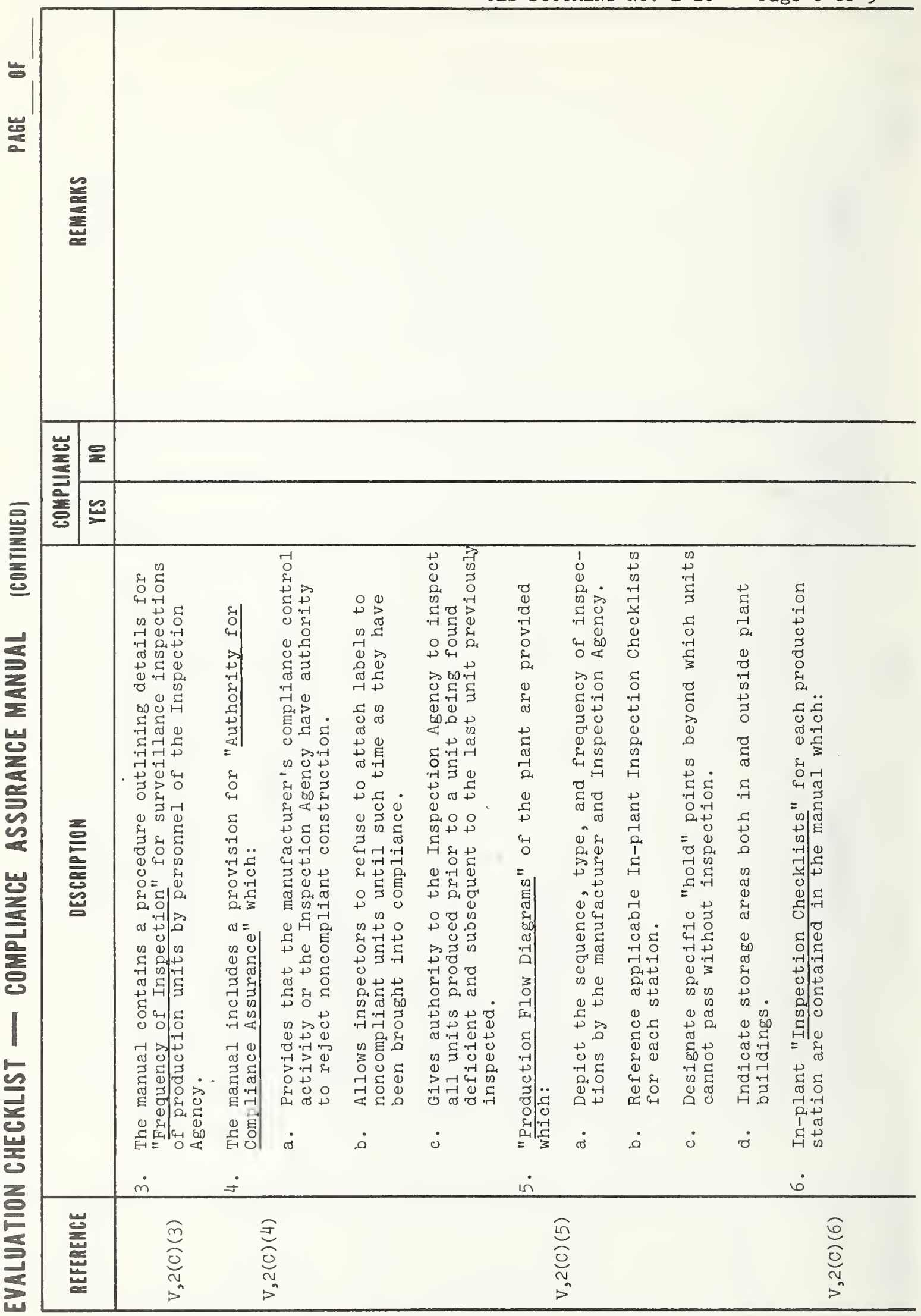




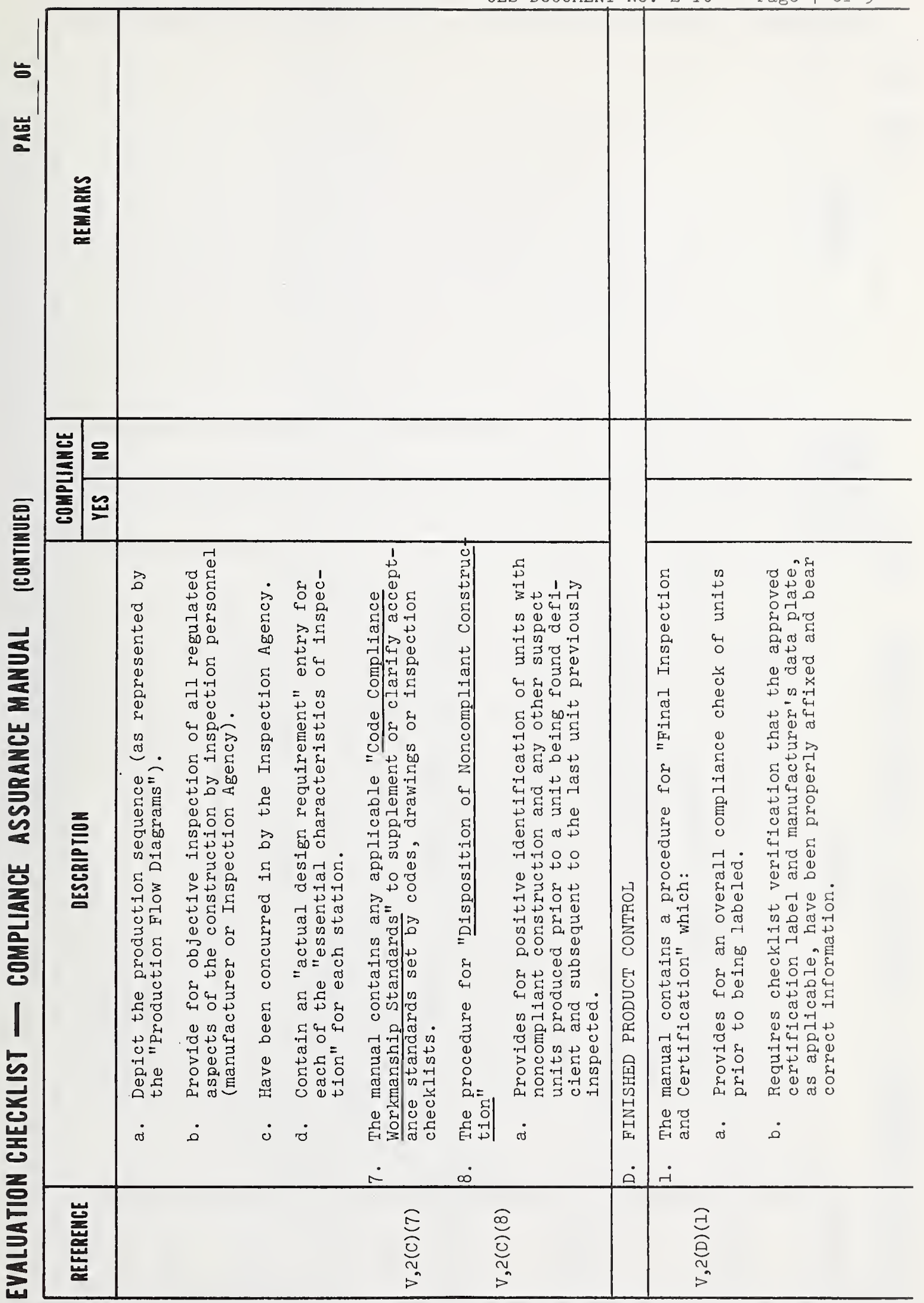




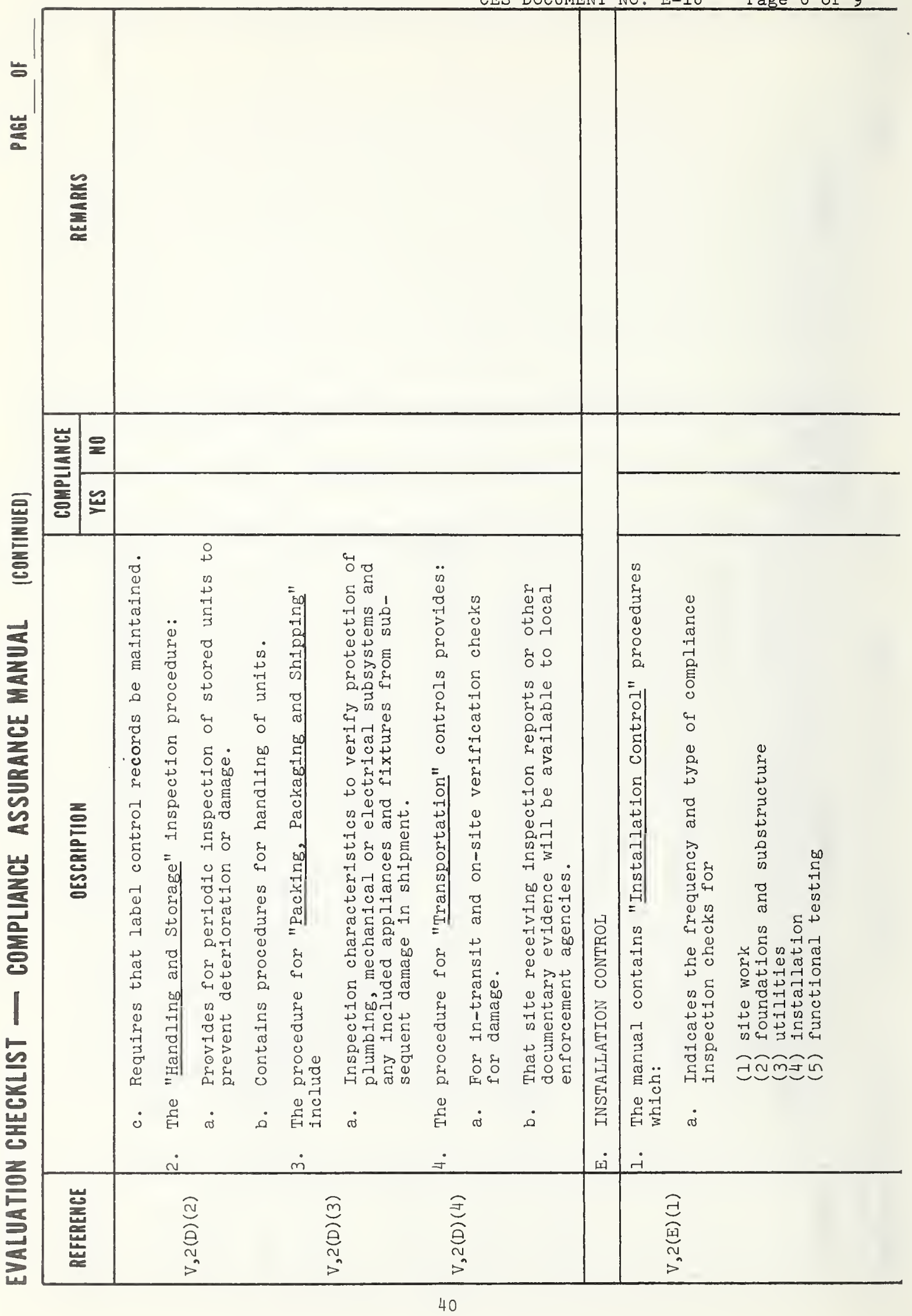




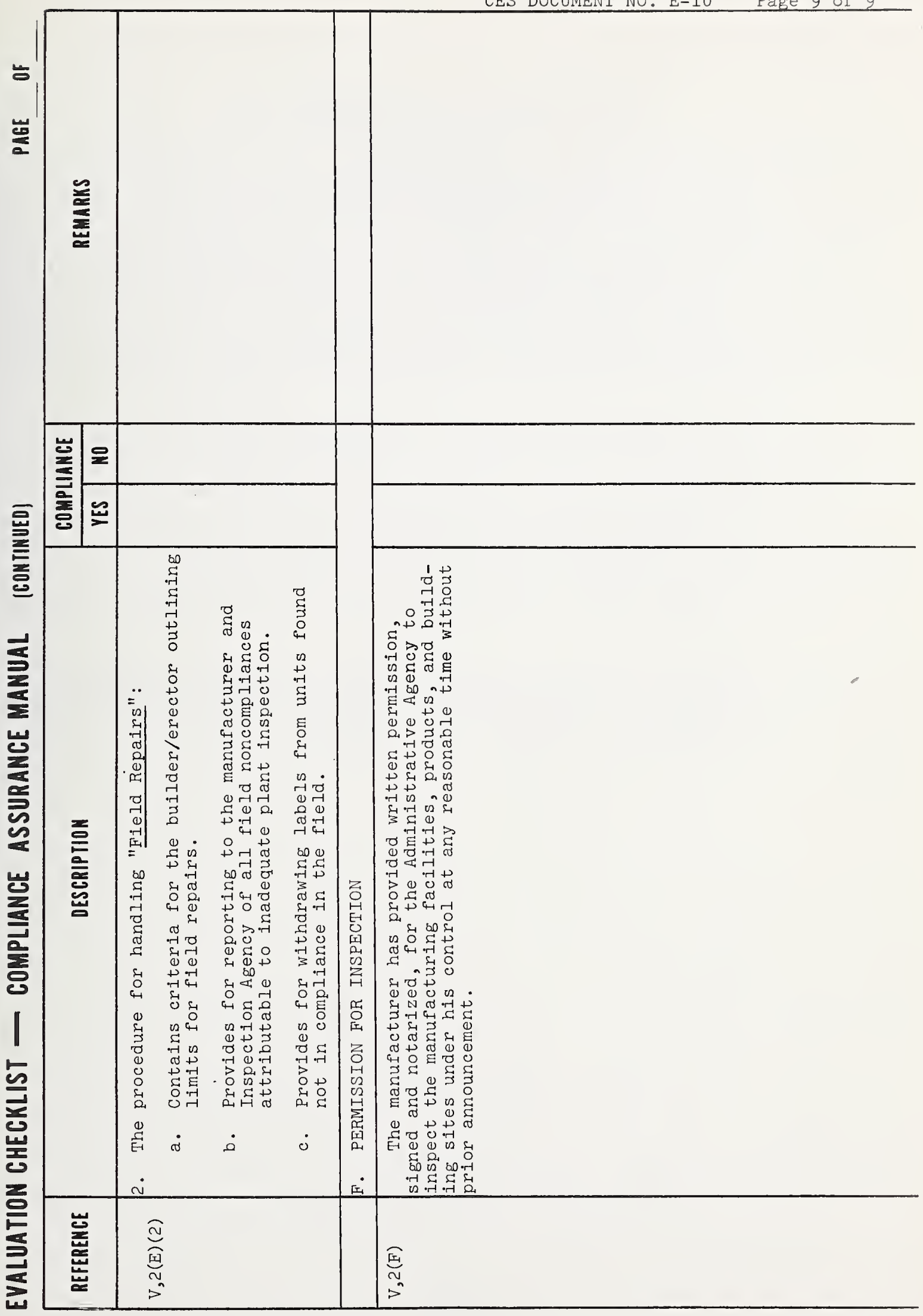




\section{MANUFACTURING FACILITY EVALUATION REPORT}

The Manufacturing Facility Evaluation Report has been developed as a suggested aid and report format for conducting the inspection survey of the manufacturer's plant facilities as required by Part IV, Section 4(A) of the Rules and Regulations. The purpose of this plant inspection by the Evaluation Agency or Administrative Agency is to determine that the provisions of the compliance assurance manual as submitted for evaluation are in fact implemented, or can be readily implemented, as soon as actual production starts (after approval of both the building system and the compliance assurance program). Where a plant is already in operation, the survey or inspection of the facility may also include the evaluation of production unit compliance.

Pages 3 and 4 of this document give a suggested checklist to be used in the plant evaluation. A suggested format to be used by the plant evaluation inspection team for reporting the results of its evaluation is given on page 2 . Page 5 is a suggested evaluation work sheet to be used when evaluating a plant in operation and where the compliance of units under production is to be included in the evaluation, and page 6 gives a suggested format for reporting the results of such unit compliance inspections. This form is to be used in conjunction with the report form given on page 2 .

The Manufacturing Facility Evaluation Report could also be utilized by the Administrative Agency in the conduct of its monitoring responsibilities of Inspection Agencies as required by Part IV, Section 4(D) of the Rules and Regulations. 


\section{STATE OF \\ Name and address of Administrative \\ Agency or Evaluation Agency \\ MANUFACTURING FACILITY EVALUATION REPORT}

NAME OF MANUFACTURER:

PLANT LOCATION:

APPLICATION NO:

BUILDING SYSTEM APPROVAL NO. (IF AVAILABLE):

NAME OF INSPECTION AGENCY:

ADDRESS :

DESCRIPTION OF BUILDING SYSTEM:

PERSONS CONTACTED (NAMES, TITLES, AFFILIATIONS):

EVALUATION TEAM SUMMARY COMMENTS - (SEE FOLLOWING PAGES OF THIS REPORT FOR DETAILS):

RECOMMENDATION :

ACCEPTABLE MANUFACTURING FACILITY EVALUATION

UNACCEPTABLE - DISAPPROVE COMPLIANCE ASSURANCE MANUAL

UNACCEPTABLE - DISAPPROVE PLANT

UNACCEPTABLE - DISAPPROVE INSPECTION AGENCY

OTHER RECOMMENDATION :

NAME, SIGNATURE AND DATE OF EVALUATION TEAM MEMBERS: 


\section{MANUFACTURING FACILITY EVALUATION REPORT}

Evaluation worksheet for determining adequacy of compliance assurance program

\begin{tabular}{|c|c|c|}
\hline \multirow{2}{*}{ AREA FOR EVALUATION } & SATISFACTORY & \multirow{2}{*}{$\begin{array}{l}\text { EXPLANATION OF } \\
\text { ITEMS CHECKED "NO" }\end{array}$} \\
\hline & & \\
\hline $\begin{array}{l}\text { Manufacturer's compliance } \\
\text { organization has independence } \\
\text { from production department. }\end{array}$ & & \\
\hline $\begin{array}{l}\text { Compliance control personnel } \\
\text { are adequately trained and } \\
\text { qualified. }\end{array}$ & & \\
\hline $\begin{array}{l}\text { Checklists for a "uniform system } \\
\text { of audits" are maintained by } \\
\text { mfgr. or Inspection Agency. }\end{array}$ & & \\
\hline $\begin{array}{l}\text { Compliance records are } \\
\text { maintained by manufacturer } \\
\text { and Inspection Agency. }\end{array}$ & & \\
\hline $\begin{array}{l}\text { Building system and compliance } \\
\text { assurance manual changes are } \\
\text { adequately controlled. }\end{array}$ & & \\
\hline $\begin{array}{l}\text { "Working drawings", if used, } \\
\text { are adequately controlled. }\end{array}$ & & \\
\hline $\begin{array}{l}\text { A unit 1dentification or serial } \\
\text { numbering system is utilized. }\end{array}$ & & \\
\hline $\begin{array}{l}\text { Certification labels are } \\
\text { adequately controlled by Inspec- } \\
\text { tion Agency and/or manufacturer. }\end{array}$ & & \\
\hline $\begin{array}{l}\text { Receiving inspection checklists } \\
\text { are utilized. }\end{array}$ & & \\
\hline $\begin{array}{l}\text { Storage and handling of material } \\
\text { is adequate. }\end{array}$ & & \\
\hline $\begin{array}{l}\text { Rejected raw materials are } \\
\text { ldentified and dispositioned. }\end{array}$ & & \\
\hline $\begin{array}{l}\text { Corrective action } 1 \text { implemented } \\
\text { and documented, as necessary. }\end{array}$ & & \\
\hline
\end{tabular}




\section{MANUFACTURING FACILITY EVALUATION REPORT}

Compliance assurance program evaluation worksheet - continued.

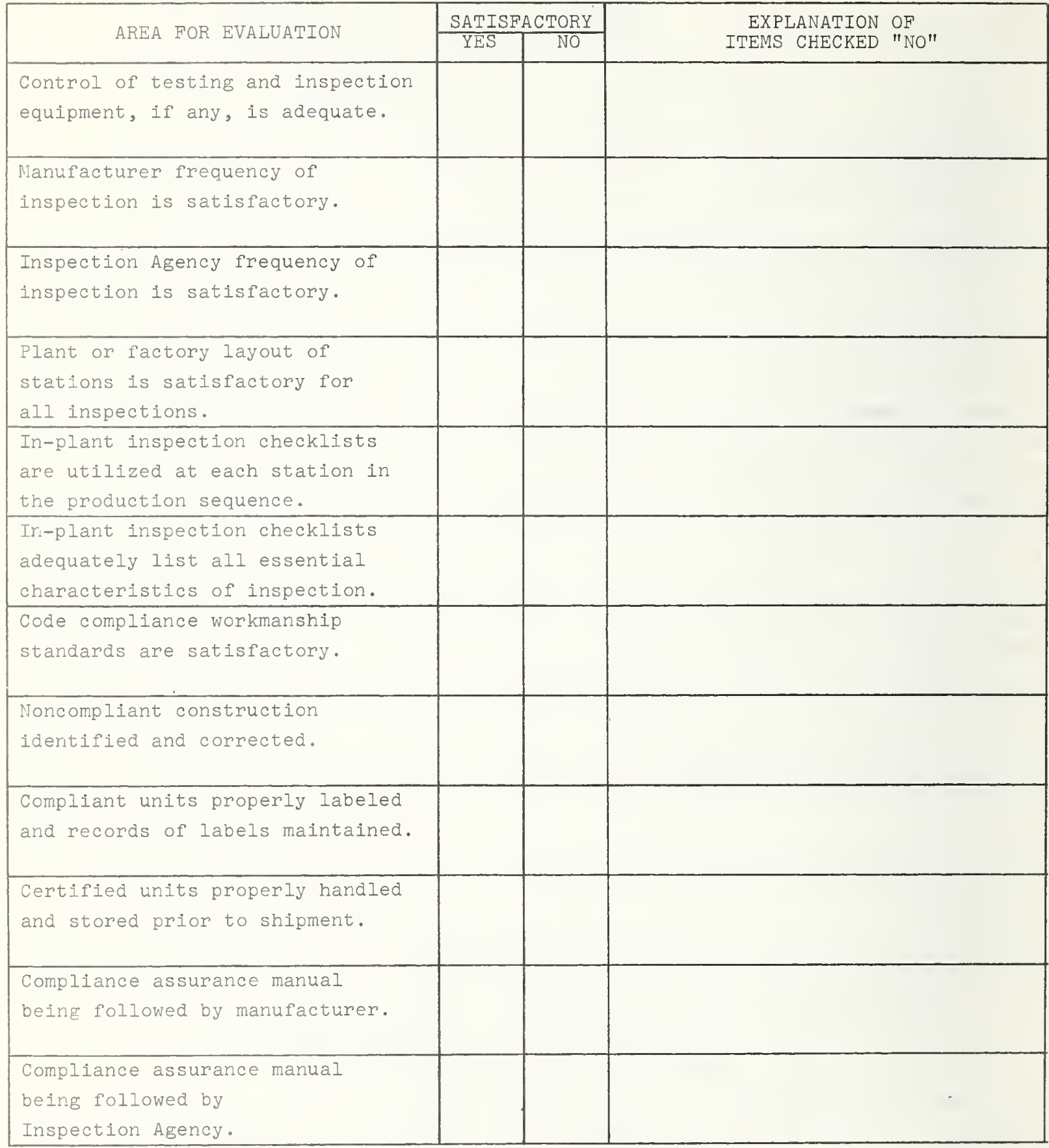




\section{MANUFACTURING FACILITY EVALUATION REPORT}

Evaluation worksheet for production unit compliance inspections by station

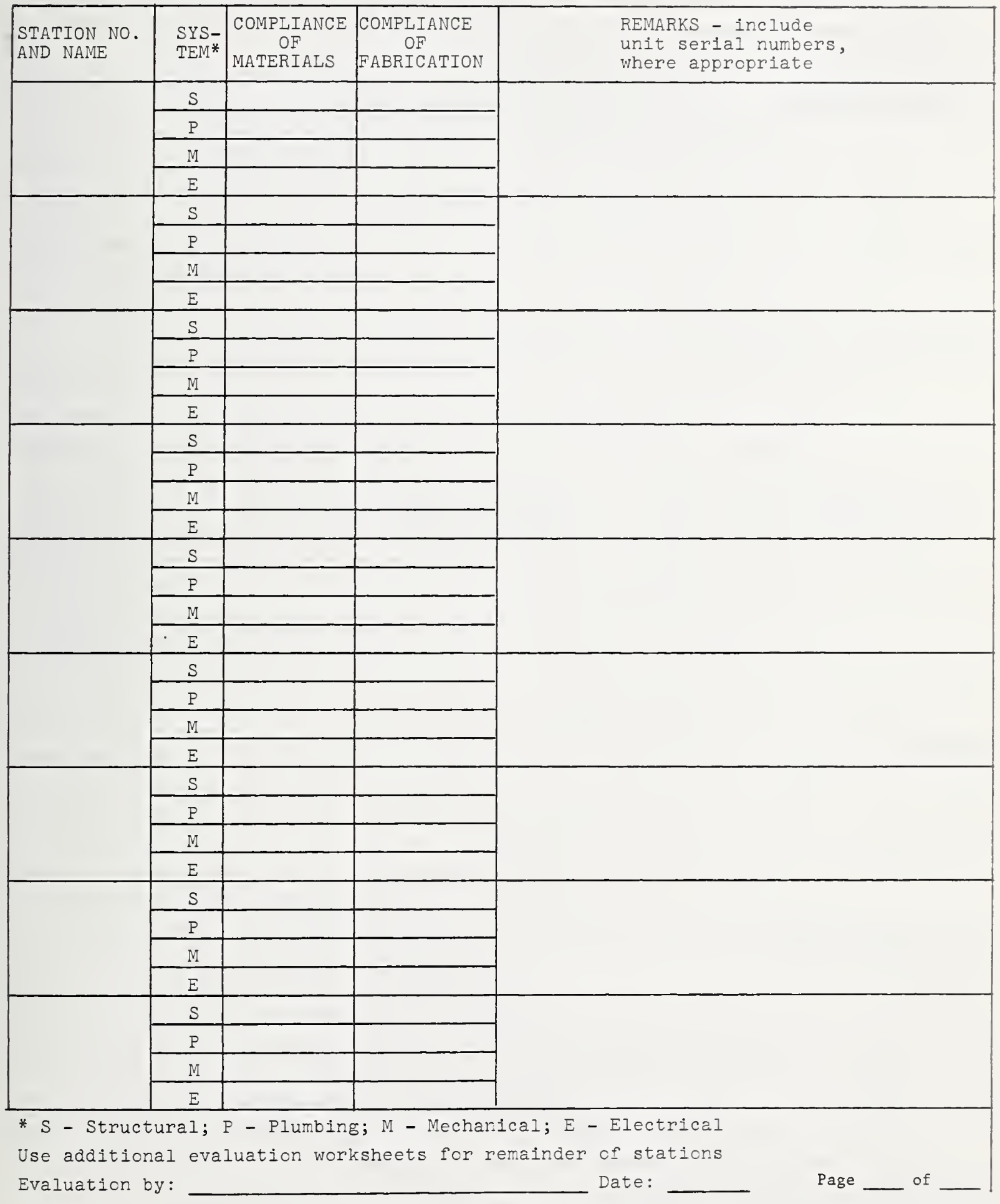




\section{MANUFACTURING FACILITY EVALUATION REPORI}

Summary findings for production unit compliance inspections by station. Describe any building system noncompliances and code violations from Production Station Evaluation Worksheets.

STRUCTURAL ELEMENTS:

\section{FIRE PROTECTION CONSIDERATIONS:}

\section{PLUMBING SYSTEM:}

\section{MECHANICAL SYSTEM:}

\section{ELECTRICAL SYSTEM:}

Use additional sheets as necessary Evaluated by: 


\section{NOTICE OF COMPLETED EVALUATION}

The purpose of the Notice of Completed Evaluation is: (1) the notification of the manufacturer of the action taken by the Evaluation Agency; (2) the statement of additional fees due to the agency or refunds due to the manufacturer (in case the sum of the deposit collected was greater than the total of fees required); and (3) if the application is disapproved, the transmittal of the reasons for such disapproval, that is, a list of deficiencies found.

Based on the above purposes, the following information should be contained in the Notice of Completed Evaluation:

1. Name and address of manufacturer;

2. Application number(s);

3. Results of evaluation (approved, disapproved);

4. Fees due by manufacturer to the Administrative or Evaluation Agency; or refund due the manufacturer;

5. In case of disapproval, a list of deficiencies found. A copy of the Evaluation Checklists (CES Documents No. E-04 to E-08 and E-10) may be used for this purpose.

6. In case of approval, a statement that after receipt of the additional fee due (if any), a copy of the approved (stamped) documents will be returned to the manufacturer (together with an approval report if application was for a building systems approval).

Page 2 of this document shows a sample form for the "Notice of Completed Evaluation". 
STATE OF

$\left[\begin{array}{c}\text { Name and Address of } \\ \text { Administrative Agency }\end{array}\right]$

Name of Manufacturer
Address

Date

RE: NOTICE OF COMPLETED EVALUATION

Building System - Appl. No.

C.A. Program - Appl. No.

Dear Sir:

Evaluation of your submission for the above application(s) has been completed. This office will issue approval documents upon remittance of evaluation fees payable to

$\square$ Evaluation of your submission for the above application(s) has been completed. Your application is disapproved for the following reasons:

Attachments:

$\square$ Evaluation Checklists

$\square$ Documents Returned

plans $\square$ specs $\square$ calculations $\square$ test data $\square$ c.A. Manual $\square$ other

$\square$ Fee Due \$

$\square$ Refund \$

Sincerely,

Signature of Agency Official

Name and Title 
STAMPS OF APPROVAL

According to the Rules and Regulations [Part IV, Section 2], the approval of building systems and compliance assurance programs is to be signified by a stamp of approval on each sheet of the submission, "or by other effective means of identification". In Part V, Section $I(A)(7)$ a space of 3 inches by 4 inches is required on all drawings of a building submission application, and a 3 by 4 inch stamp is used for signifying approval on such drawings. This is in conformance with current practice in many states, and provides sufficient space for the information required on the stamp. Although a similar space is not mandatory on compliance assurance program submissions, the same stamp should be used on the first page or on the cover of the compliance assurance manual, as well as on specifications which may be submitted with a building system. However, the single pages of a compliance assurance manual or of a set of specifications can not conveniently be stamped with a 3 inch by 4 inch stamp. Accordingly, an "other means of identification" of such pages should be used which is smaller and need not contain all the information required on the larger approval stamp. Accordingly, it is suggested that a smaller and simpler stamp be used for such pages. The contents of both stamps are discussed in this document.

Contents of Stamp of Approval

A 2-7/8 1nch by 3-7/8 1nch stamp of approval should be used. Such stamp should contain as a minlmum the following information:

1. Identification of State

2. Identification of Administrative Agency or of Evaluation Agency (if different from the former).

3. A statement that the plans and/or compliance assurance manual have been approved pursuant to the applicable legislation (identify enabling legislation and regulations).

4. A statement that this approval does not authorize any deviation or omissions from valid state or local laws.

5. A statement that the approval of either a building system or a compliance assurance program alone does not authorize the certification of units built according to such system or manual, but that approval for both must be obtained.

6. Approval number.

7. Space for signature of authorized person (including title) and the approval date.

In some states additional information is given on the approval stamp, such as design loads, occupancy class, etc. However, if such information is contained in the Building System Approval Report (CES Document No. A-03) it appears that it need not be repeated on each stamp. 


\section{Contents of Alternate Stamp}

For identifying typewritten pages, such as in a compliance assurance manual, it is suggested that an alternate stamp be used. Such stamp should not be used singly, but only in conjunction with an approval stamp as described above.

The content of such an alternate stamp should be as simple as possible while still performing the function of "identifying" the pages. Accordingly, it is suggested that only the following items be shown.

1. Identification of state;

2. Identification of approving agency;

3. Approval number.

It is suggested that such stamp be not greater than $3 / 4$ inch by 2 inch so that it can be placed conveniently on the margin of typewritten pages.

On Page 3 of this document samples for both the Approval stamp and for the Alternate stamp are shown. 


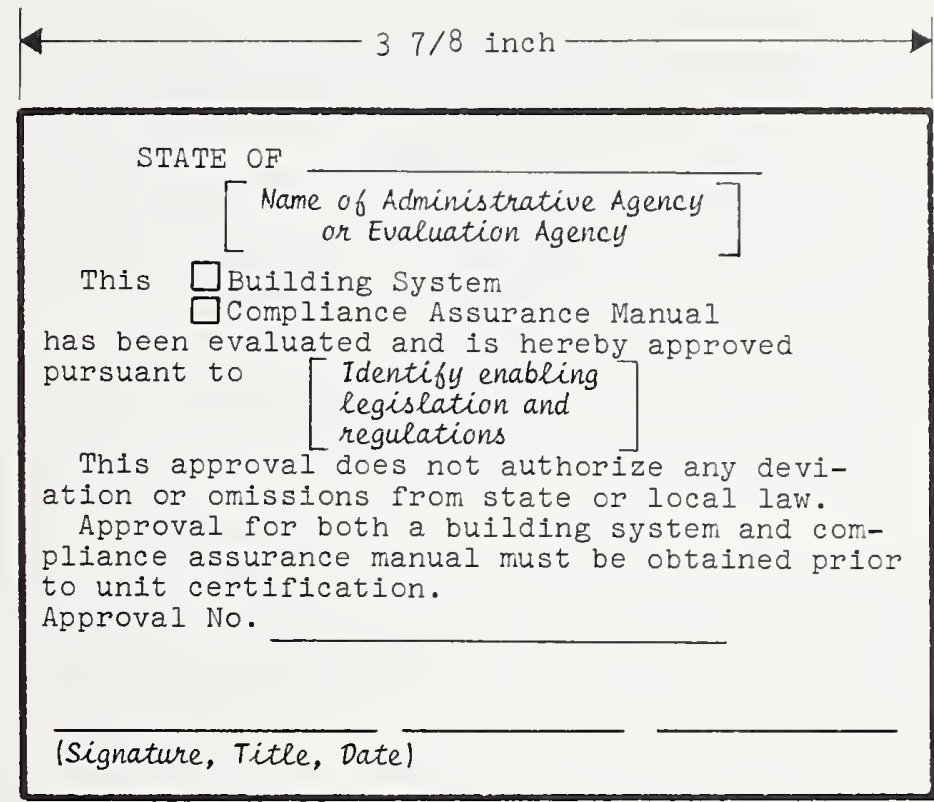

Approval stamp for signifying approval of drawings and

front page of typed or printed documents.

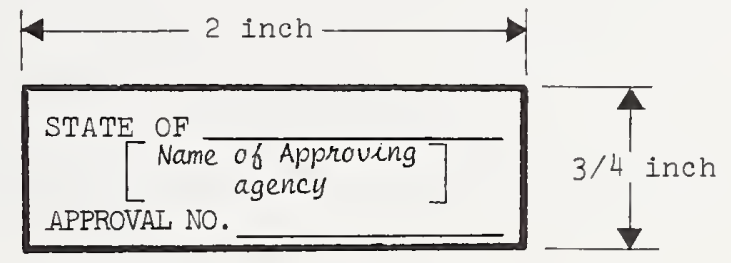

Alternate Approval stamp for signifying approval of typed or printed pages. 

The main purposes of the building system approval report are: (1) to notify the manufacturer of the approval of his submission, and (2) indicate the conditions of such approval, particularly a limitation imposed on the use of the building system. In addition, the report serves to transmit such information to the local enforcement agency in whose jurisdiction the manufactured building or building component is to be installed, or to other states in which the manufacturer applies for approval based on reciprocity.

The approval report should contain the following information:

I. Type of Approval: This indicates whether a new system is being approved or a modification, and gives all pertinent approval and application numbers, dates, etc.

II. Identification: In this section the manufacturer, the location of his plant, and any Inspection Agency and/or architect/engineer involved in the design are identified.

III. Documents Submitted: All documents which formed the basis for the approval are to be listed.

IV. Description of Manufactured Building or Component: This section gives pertinent information regarding the approved building or component, including items such as type of occupancy, type of construction, principal construction materials and design parameters (loads and temperatures).

V. Details of Construction: This is a brief description of all major construction systems which form part of the building or component.

VI. Applicable Codes or Standards: The codes and standards used as a basis for the technical evaluation are to be noted in this section."

VII. Installation Instructions: A discussion or list of critical items or provisions that must be observed in the preparation for and installation of certified units on the site.

VIII. Limitations of Approval: Any use limitations of the approved building system, other than those inherent in the information given in IV above, should be clearly stated.

In addition, the name, title, and signature of the person preparing the approval report and of the agency official also must appear on the document.

A sample approval form is given on the following two pages. 


\section{STATE OF}

\section{$\left[\begin{array}{c}\text { Name and Address of } \\ \text { Administrative Agency }\end{array}\right]$}

\section{BUILDING SYSTEM APPROVAL REPORT}

I. TYPE OF APPROVAL $\square$ New System $\square$ Modification APPROVAL REPORT NO.

Date of Approval Expiration Date

Previous Approval Nos: $\square$ Building System $\square$ C.A. Program Building System Application No. Date

II. IDENTIFICATION

Name of Manufacturer

Address

Location of Manufacturing Plant

Name of Inspection Agency

Address

Name of Reg. Architect/Prof. Engineer

Reg. No.

Address

State

III. DOCumENTs subMITTED $\square$ Plans $\square$ specs $\square$ Test Data $\square$ shop Dwgs. $\square$ c.A.Manual $\square$ sample $\square$ Calculations (Type)

$\square$ other state or Agency Approvals/Listings

IV. DESCRIPTION OF MANUFACTURED BUILDING OR COMPONENT

A. Occupancy: $\square$ one and Two Family Detached $\square$ other (Specify)

B. Type of Construction (classification)

C. Type of System: $\square$ Unitized Modular $\square$ Core Unit $\square$ component $\square$ Architectural $\square$ Structural $\square$ Mechanical $\square$ plumbing $\square$ Electrical $\square$ other (Specify)

D. Principal Construction Material: $\square$ wood $\square$ concrete $\square$ steel $\square$ Masonry $\square$ other (Specify)

E. Energy Source: Heating Cooling

F. Design Parameters: Live Load__Wind Load___ Snow Load

G. Design Temperatures: Summer Winter Seismic Load

DETAILS OF CONSTRUCTION

Structure:

Walls and Partitions:

Floor - Ceiling:

Roof - Ceiling: 
BUILDING SYSTEM APPROVAL REPORT (continued)

DETAILS OF CONSTRUCTION (continued)

Mechanical:

Electrical:

Plumbing:

Other:

VI. APPLICABLE CODES OR STANDARDS

VII. INSTALLATION INSTRUCTIONS

VIII. LIMITATIONS OF APPROVAL (IF ANY)

This is a Building system approval only. For manufactured buildings and/or building components to be certified, an approved concurrent C.A. Program is also required.

Prepared by (Name)

Signature

Date

Signature of Agency official Date

Name and Title

(Space for Stamp or Seal) 
